Article

\title{
Influence of the synthesis method parameters used to prepare nickel-based catalysts on the catalytic performance for the glycerol steam reforming reaction
}

\author{
M. A. Goula*, N. D. Charisiou, K. N. Papageridis, G. Siakavelas \\ Technological Education Institution of Western Macedonia, School of Technological Applications, Department of Environmental and Pollution Control \\ Engineering, Laboratory of Alternative Fuels and Environmental Catalysis, GR-50100 Koila, Kozani, Greece
}

\section{A R T I C L E I N F O}

\section{Article history:}

Received 31 May 2016

Accepted 24 July 2016

Published 5 November 2016

\section{Keywords:}

Glycerol

Hydrogen

Steam reforming

Supported nickel catalyst

Catalyst preparation

\begin{abstract}
A B S T R A C T
The influence of the synthesis method parameters used to prepare nickel-based catalysts on the catalytic performance for the glycerol steam reforming reaction was studied. A series of $\mathrm{Al}_{2} \mathrm{O}_{3}$-supported $\mathrm{Ni}$ catalysts were synthesized, with nickel loading of $8 \mathrm{wt} \%$, using the incipient wetness, wet impregnation, and modified equilibrium deposition filtration methods. The catalysts' surface and bulk properties were determined by inductively coupled plasma (ICP), $\mathrm{N}_{2}$ adsorption-desorption isotherms (BET), X-ray diffraction (XRD), scanning electron microscopy (SEM), transmission electron microscopy (TEM), and temperature-programmed reduction (TPR). Used catalysts were characterized by techniques such as elemental analysis and SEM in order to determine the level of carbon that was deposited and catalyst morphology. The results indicated that the synthesis method affected the textural, structural and surface properties of the catalysts, differentiating the dispersion and the kind of nickel species on alumina's surface. The formation of nickel aluminate phases was confirmed by the XRD and TPR analysis and the $\beta$-peak of the Ni/Al-edf catalyst was higher than in the other two catalysts, indicating that the nickel aluminate species of this catalyst were more reducible. Both $\mathrm{Ni} / \mathrm{Al}$-wet and $\mathrm{Ni} / \mathrm{Al}$-edf catalysts showed increasing $\mathrm{CO}_{2}$ selectivities and approximately constant $\mathrm{CO}$ selectivities for temperatures above $550{ }^{\circ} \mathrm{C}$, indicating that these catalysts successfully catalyze the water gas shift reaction. It was also confirmed that the $\mathrm{Ni} / \mathrm{Al}$-edf catalyst had the highest values for glycerol to gaseous products conversion, hydrogen yield, allyl alcohol, acetaldehyde, and acetic acid selectivities at $650^{\circ} \mathrm{C}$ and the lowest carbon deposition of the catalysts tested. The correlation of the catalysts' structural properties, dispersion and reducibility with catalytic performance reveals that the EDF method can provide catalysts with higher specific surface area and active phase's dispersion, that are easier to reduce, more active and selective to hydrogen production, and more resistant to carbon deposition.
\end{abstract}

(C) 2016, Dalian Institute of Chemical Physics, Chinese Academy of Sciences. Published by Elsevier B.V. All rights reserved.

\section{Introduction}

The increase in biodiesel development means that the disposal of crude glycerol is an emerging issue because the transesterification reactions to produce biodiesel yield $10 \mathrm{wt} \%$ glycerol as a by-product. Among various methods of crude glycerol disposal and utilization, the glycerol steam reforming reaction (GSR) provides the potential to produce renewable hydrogen gas. This process could substantially improve the viability of numerous bio-refining processes [1-4].

\footnotetext{
* Corresponding author. Tel: +30-2461068296; Fax: +30-2461039682; E-mail: mgoula@teiwm.gr

DOI: 10.1016/S1872-2067(16)62518-4 | http://www.sciencedirect.com/science/journal/18722067 | Chin. J. Catal., Vol. 37, No. 11, November2016
} 
The GSR can be represented by Eq. (1) and can be considered as combination of glycerol decomposition (Eq. (2)) and a water-gas shift (WGS) reaction (Eq. (3)).

$$
\begin{aligned}
\mathrm{C}_{3} \mathrm{H}_{8} \mathrm{O}_{3}+3 \mathrm{H}_{2} \mathrm{O} & \rightarrow 3 \mathrm{CO}_{2}+7 \mathrm{H}_{2} \\
\mathrm{C}_{3} \mathrm{H}_{8} \mathrm{O}_{3} & \rightarrow 3 \mathrm{CO}^{2}+4 \mathrm{H}_{2} \\
\mathrm{CO}+\mathrm{H}_{2} \mathrm{O} & \leftrightarrow \mathrm{CO}_{2}+\mathrm{H}_{2}
\end{aligned}
$$

These pathways maybe accompanied by other reactions as shown in Eqs. (4)-(12) [5-7].

$$
\begin{aligned}
\mathrm{CO}+3 \mathrm{H}_{2} & \leftrightarrow \mathrm{CH}_{4}+\mathrm{H}_{2} \mathrm{O} \\
2 \mathrm{CO} & \leftrightarrow \mathrm{CO}_{2}+\mathrm{C} \\
\mathrm{CH}_{4}+2 \mathrm{H}_{2} \mathrm{O} & \leftrightarrow \mathrm{CH}_{2}+4 \mathrm{H}_{2} \\
\mathrm{CH}_{4}+\mathrm{CO}_{2} & \leftrightarrow 2 \mathrm{H}_{2}+2 \mathrm{CO} \\
\mathrm{CH}_{4} & \leftrightarrow 2 \mathrm{H}_{2}+\mathrm{C} \\
\mathrm{C}+2 \mathrm{H}_{2} \mathrm{O} & \leftrightarrow 2 \mathrm{H}_{2}+\mathrm{CO}_{2} \\
\mathrm{H}_{2} \mathrm{O}+\mathrm{C} & \leftrightarrow \mathrm{CO}+\mathrm{H}_{2} \\
\mathrm{C}_{3} \mathrm{H}_{8} \mathrm{O}_{3}+5 \mathrm{H}_{2} & \leftrightarrow 3 \mathrm{CH}_{4}+3 \mathrm{H}_{2} \mathrm{O} \\
\mathrm{C}_{3} \mathrm{H}_{8} \mathrm{O}_{3} & \rightarrow \mathrm{H}_{2}+3 \mathrm{H}_{2} \mathrm{O}+3 \mathrm{C}
\end{aligned}
$$

The fundamental steps involve the cleavage of $\mathrm{C}-\mathrm{C}, \mathrm{O}-\mathrm{H}$ and $\mathrm{C}-\mathrm{H}$ bonds of the glycerol molecule, while maintaining the $\mathrm{C}-\mathrm{O}$ bonds. The reaction pathways and product distribution are determined to a large extent by the catalyst. A number of studies reporting the performance of different catalytic systems for the GSR have steadily been published in the last few years, with Ni-based systems attracting the most attention [7-12].

Ni-based catalysts have attracted researchers' interest due to their lower cost and higher availability than noble metal catalysts, and they have considerable intrinsic activity, especially when the $\mathrm{Ni}$ is highly dispersed over a support. Alumina-based supports have been investigated because of their mechanical and chemical resistance under the reaction conditions, and because of alumina's high specific surface area (SSA), which improves metal dispersion. However, Ni on alumina catalysts suffers from deactivation by carbon formation (with carbon tending to deposit and cover the active sites of the catalyst surface), and metal particle sinterization, caused by a lack of adequate thermal stability [13-22].

Maximization of the active phase dispersion, optimization of the active species, and decreasing the rate of coke deposition on the catalysts' surfaces are major challenges for Ni-based catalysts used in reforming reactions. These problems may be mitigated by developing an appropriate methodology for the preparation of catalysts. Different techniques have been employed for the preparation of GSR catalysts including self-combustion, ionic exchange, sol gel, microemulsion and precipitation $[6,8,14,16]$. However, the most popular synthetic methods by far have been the incipient wetness and wet impregnation techniques [3-5,10,12,13].

The equilibrium deposition filtration technique (EDF), otherwise called equilibrium adsorption [23,24], to the best of our knowledge, has not been used to prepare GSR catalysts. Using EDF, active species are deposited not only by adsorption but by reaction with the receptor sites developed on the support surface (surface oxygens and surface hydroxyls) during the long equilibration time of the quite dilute, impregnating suspensions, giving catalysts with promising textural, structural, and expected catalytic properties.

The aim of our work was to comparatively investigate the influence of the catalysts' synthesis method on surface characteristics and catalytic performance for the GSR. A series of $\mathrm{Al}_{2} \mathrm{O}_{3}$-supported $\mathrm{Ni}$ catalysts were prepared, with nickel loadings of $8 \mathrm{wt} \%$, using the incipient wetness, wet impregnation and a slightly modified EDF techniques. The catalysts' surface and bulk properties, at their calcined, reduced and used forms, were determined by applying several characterization techniques including inductively coupled plasma (ICP), $\mathrm{N}_{2}$ adsorption-desorption, X-ray diffraction (XRD), scanning electron microscopy (SEM), transmission electron microscopy (TEM), temperature-programmed reduction (TPR) and carbon analysis. The catalysts' performance was studied to investigate the effect of reaction temperature on (1) glycerol total conversion, (2) glycerol conversion to gaseous products, (3) hydrogen selectivity and yield, (4) selectivity of gaseous products, (5) selectivity of liquid products, and (6) molar ratios of $\mathrm{H}_{2} / \mathrm{CO}$ and $\mathrm{CO} / \mathrm{CO}_{2}$ in the gaseous products mixture. Investigating the influence of the catalysts' synthesis method on their surface characteristics and catalytic performance also provided additional information on the correlation between the physicochemical and catalytic properties of the reforming catalysts.

\section{Experimental}

\subsection{Preparation of catalysts}

A commercial $\gamma-\mathrm{Al}_{2} \mathrm{O}_{3}$ (Akzo) was used as the support for all the Ni-based catalysts with its physicochemical properties published elsewhere [25]. The support was purchased in pellet form and crashed and sieved to $350-500 \mu \mathrm{m}$ before use. The powder was air-dried overnight and calcined at $800{ }^{\circ} \mathrm{C}$ for $5 \mathrm{~h}$ under an atmosphere of air.

The catalysts were prepared via the EDF (slightly modified), wet impregnation and incipient wetness impregnation techniques using nickel nitrate aqueous solutions $(0.17 \mathrm{~mol} / \mathrm{L})$, in order to obtain catalysts with $\mathrm{Ni}$ content of about $8 \mathrm{wt} \%$. The $\mathrm{Ni}\left(\mathrm{NO}_{3}\right)_{2} \cdot 6 \mathrm{H}_{2} \mathrm{O}$ used for the catalyst preparation was obtained from Sigma Aldrich. All solutions for catalyst preparation utilized distilled and de-ionized pure water generated by a NANOpure Diamond UV unit (Barnstead International).

The modified EDF sample (labeled herein as Ni/Al-edf) was prepared at constant impregnating solution temperature and a $\mathrm{pH}$ value of $25.0 \pm 0.1^{\circ} \mathrm{C}$ and 7.0 , respectively. The point of zero charge of the $\gamma$-alumina was determined to be close to a $\mathrm{pH}$ value of 7.0, i.e., at this $\mathrm{pH}$ the positive and negative charge sites on the alumina surface are equal. The catalyst was prepared in a temperature controlled vessel $(250 \mathrm{~mL})$ equipped with a $\mathrm{pH}$ adjusting and controlling device, involving a glass/saturated calomel electrode (Metro 703 Ti Stand). The pH control system allowed the automatic adjustment of the $\mathrm{pH}$ during the impregnation by addition of $0.1 \mathrm{~mol} / \mathrm{L} \mathrm{NH}_{4} \mathrm{OH}$ aqueous solution. Nitrogen gas was bubbled into the vessel during the preparation process to prevent dilution of the atmospheric $\mathrm{CO}_{2}$ and subsequent change in the $\mathrm{pH}$. A 100-mL nickel nitrate solution was used. The ionic strength of the solution was adjusted to 0.1 mol/L throughout the impregnation with $\mathrm{NH}_{4} \mathrm{NO}_{3}$. The $\gamma$-alumina (10 g) was added to the solution and kept under stirring. 
The $\mathrm{pH}$ was kept at 7.0 for about $2.5 \mathrm{~h}$, and then the water was evaporated using a rotary evaporator at $60^{\circ} \mathrm{C}$ for $4 \mathrm{~h}$.

The catalyst synthesized by the wet impregnation method (labeled herein as $\mathrm{Ni} / \mathrm{Al}$-wet) used an impregnation solution volume that was about 10 times higher than the alumina's pore volume $\left(V_{\mathrm{p}}\right)$, and the water was evaporated using a rotary evaporator at $60{ }^{\circ} \mathrm{C}$ for $4 \mathrm{~h}$. The $\mathrm{pH}$ (initial $\mathrm{pH}$ value 5.5 ) was not adjusted or controlled during the catalyst's preparation.

The incipient wetness impregnation sample (labeled herein as $\mathrm{Ni} / \mathrm{Al}$-iwi) was prepared using simple pore volume $\left(V_{\mathrm{p}}\right) \mathrm{im}$ pregnation. The volume of nickel nitrate aqueous solution used was equal to the total $V_{\mathrm{p}}$ of the impregnated alumina. The impregnation solution was added dropwise to the support and mixed. The support became slightly wet after the addition was complete. The catalyst samples were air-dried overnight and then calcined at $800^{\circ} \mathrm{C}$ for $5 \mathrm{~h}$ under an atmosphere of air.

\subsection{Characterization}

The SSA of the catalysts were measured using $\mathrm{N}_{2}$ adsorption-desorption isotherms at $-196{ }^{\circ} \mathrm{C}$, following the Brunauer-Emmett-Teller (BET) equation at relative pressures in the range of $0.05-0.30$, with a Nova 2200e (Quantachrome). The SSAs were measured on the calcined and reduced samples.

The $V_{\mathrm{p}}$ calculation of both calcined and reduced catalysts was based on the nitrogen volume adsorbed at the highest relative pressure, whereas the adsorption average pore size diameter was calculated using the equation $4 V / A$ by BET. The adsorption and desorption average pore width $\left(D_{\mathrm{a}}\right)$ was determined by the Barrett-Joyner-Halenda (BJH) method. The samples were degassed at $350{ }^{\circ} \mathrm{C}$ for $5 \mathrm{~h}$ under vacuum prior to the measurements.

The total metal loading (wt\%) of each of the final catalysts was determined by ICP atomic emission spectroscopy on a Perkin-Elmer Optima 4300DV apparatus using a previously described method [23]. Metal loading was measured for the calcined samples.

The catalyst crystalline structure was determined by XRD using a Siemens D500 diffractometer at $40 \mathrm{kV}$ and $30 \mathrm{~mA}$ with $\mathrm{Cu} K_{\alpha}$ radiation $(\lambda=0.154 \mathrm{~nm})$. Diffractograms were recorded in the $2 \theta=2^{\circ}-70^{\circ}$ range at a scanning rate of $0.02^{\circ}$ over $2 \mathrm{~s}$. The diffraction patterns were identified by comparison with those of known structures in the Joint Committee of Powder Diffraction Standards database. The XRD technique was used for both calcined and reduced samples.

$\mathrm{H}_{2}$-TPR experiments were carried out in a conventional quartz bed reactor with a feed of $\mathrm{H}_{2}(5 \%) / \mathrm{He}$ flowing at 50 $\mathrm{mL} / \mathrm{min}$. Calcined samples $(100 \mathrm{mg})$ were heated at a rate of 10 ${ }^{\circ} \mathrm{C} / \mathrm{min}$ from 25 to $900{ }^{\circ} \mathrm{C}$. The catalysts were subjected to an initial pretreatment step using $\mathrm{He}(50 \mathrm{~mL} / \mathrm{min})$ before the reduction procedure. This treatment included preheating up to $600{ }^{\circ} \mathrm{C}$ at a heating rate of $3{ }^{\circ} \mathrm{C} / \mathrm{min}$ and then holding at this temperature for $1 \mathrm{~h}$. The outlet gas was analyzed by mass spectrometry (MS). The main $m / z$ fragment registered was that of $\mathrm{H}_{2}=2$.

Conventional TEM and high resolution TEM experiments were carried out in a JEOL JEM-2011 electron microscope, op- erating at $200 \mathrm{kV}$ with a point resolution of $0.23 \mathrm{~nm}$. The instrument was fitted with an energy-dispersive X-ray spectroscopy (EDS) detector for the elemental analysis of the samples. Qualitative and semi-quantitative analysis of EDS data was accomplished using the INCA microanalysis software package. Samples were prepared according to a previously described procedure [23].

Morphological examination of both fresh and used catalysts was undertaken using SEM in a JEOL 6610LV. The EDS elemental analysis was carried out using a large area $\left(80 \mathrm{~mm}^{2}\right)$ silicon drift detector (X-Max 80 0xford Instruments). Images, element maps and spectra were acquired and analyzed with the AZtech Nanoanalysis software (Oxford Instruments).

The percentile concentration of carbon in the used catalyst was measured by quantitative infrared spectroscopy performed with a Leco CHN-200 analyzer. Sample (0.1 g) and accelerator material ( $0.1 \mathrm{~g}$ of Lecocel), which was used to ensure complete coupling of the sample and RF field, were weighted into a ceramic crucible and the crucible placed on the loading pedestal for analysis. Furnace closure was performed automatically and the combustion chamber purged with oxygen (99.9\%) to drive off residual atmospheric gases. Oxygen flow through the system was restored after purging and the induction furnace turned on. The inductive elements of the sample and accelerator couple with the high frequency field of the furnace. The pure oxygen atmosphere and the heat generated by this coupling cause the sample to combust. During combustion, carbon bearing elements are reduced, releasing the carbon, which immediately binds with the oxygen atmosphere to form $\mathrm{CO}$ and $\mathrm{CO}_{2}$. Sample gases are swept into the carrier stream $\left(\mathrm{N}_{2}\right.$, $99.9 \%$ ). A small amount of $\mathrm{CO}_{2}$ is converted to $\mathrm{CO}_{2}$ in the catalytic heater assembly and carbon is measured as $\mathrm{CO}_{2}$ in the infrared (IR) cell as gases flow through the IR cells.

\subsection{Catalytic tests}

The GSR was carried out at atmospheric pressure in a continuous flow, fixed-bed, single pass, tubular stainless steel reactor with an inner diameter of $14 \mathrm{~mm}$ at temperatures ranging from 400 to $750{ }^{\circ} \mathrm{C}$. The experimental set up had two vaporizers, a pre-heater before the reactor and a condenser after it, allowing the feeding of both liquid and gaseous streams. The vaporizers, pre-heater and reactor were placed into electrical ovens and regulated with programmed-temperature controllers (Fig. 1).

Catalyst (200 mg) was reduced in situ under a flow of $100 \%$ $\mathrm{H}_{2}(100 \mathrm{~mL} / \mathrm{min})$ at $800{ }^{\circ} \mathrm{C}$ for $1 \mathrm{~h}$ prior to catalytic testing. The catalyst was purged with He for $45 \mathrm{~min}$, the temperature lowered to $750{ }^{\circ} \mathrm{C}$ and the reaction feed was introduced into the catalyst bed. Each step lasted for approximately $50 \mathrm{~min}$ in order to ensure operation at steady state conditions. This timeframe allowed three measurements of the gas products at each temperature, helping to ensure the reliability of the results. Liquid products were obtained at the end of each 50-min period.

The reaction feed consisted of the gas stream (He 5.0, 38 $\mathrm{mL} / \mathrm{min}$ ) and the liquid stream (an aqueous solution of 20:80 


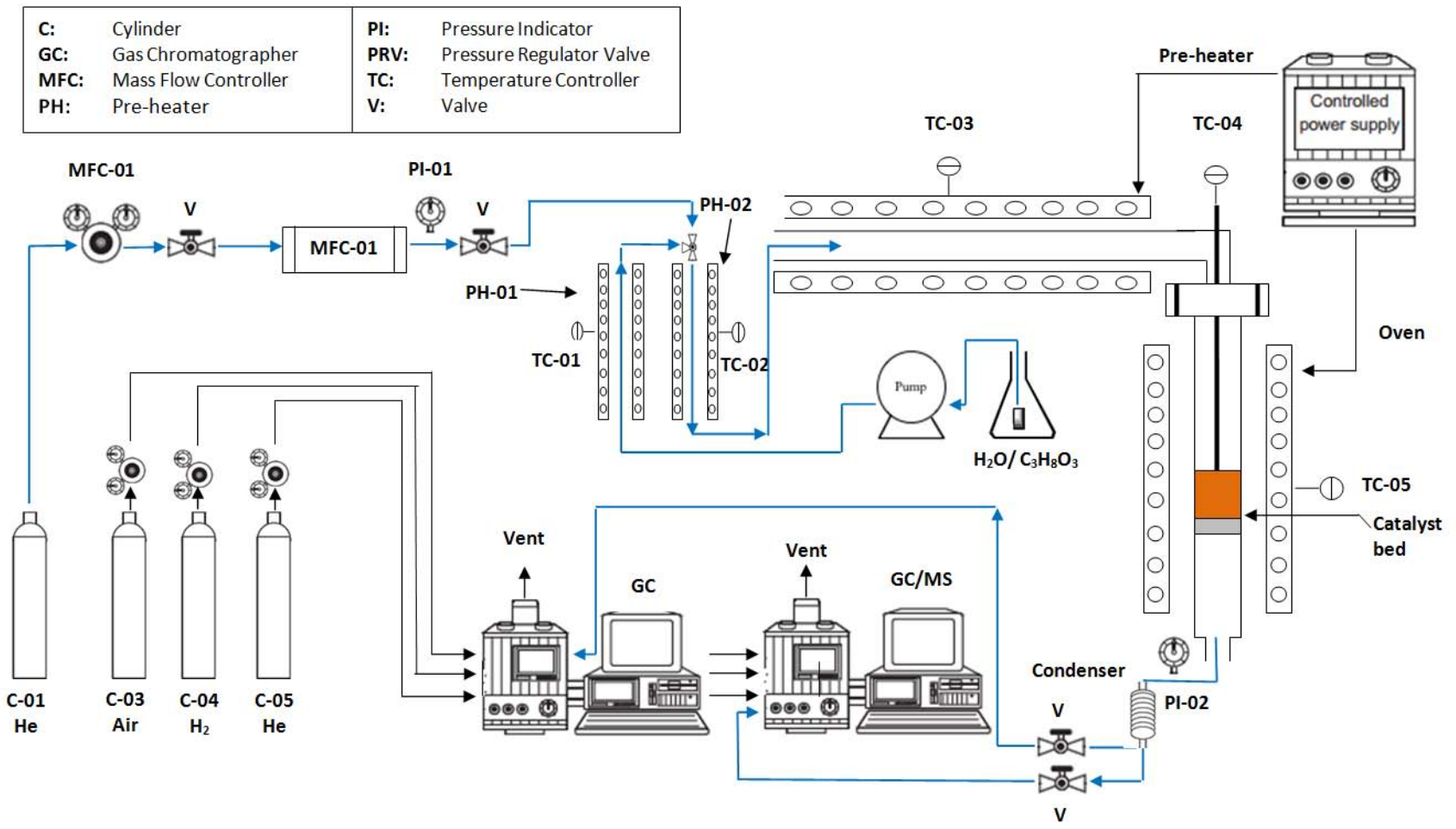

Fig. 1. Schematic flow chart of experimental setup for activity test of catalysts towards glycerol steam reforming.

(wt\%) $\mathrm{C}_{3} \mathrm{H}_{8} \mathrm{O}_{3}$ and $\mathrm{H}_{2} \mathrm{O}, 20: 1$ steam/glycerol molar ratio, with a total liquid flow rate of $0.12 \mathrm{~mL} / \mathrm{min}$, which was kept under continuous stirring at room temperature). The glycerol $(99.5 \%$ purity) was obtained from Sigma Aldrich. The glycerol/water mixture was fed with a high-performance liquid chromatography pump (Series I) into the evaporator and was vaporized at $350{ }^{\circ} \mathrm{C}$ before it was mixed with He. Pressure controllers were placed before and after the inlet and outlet gas ports to prevent over pressurization. The gas feed to the reactor was a gaseous mixture of $73 \% \mathrm{H}_{2} \mathrm{O}, 4 \%$ glycerol and $23 \% \mathrm{He}$, corresponding to a weight hourly space velocity (WHSV) of $50000 \mathrm{~mL} \mathrm{~g}^{-1} \mathrm{~h}^{-1}$. The reactor's outlet gases passed through a cold trap for liquid product capture.

The gaseous products were analyzed on-line by gas chromatography (Agilent 7890A), with two columns in parallel, an HP-Plot-Q (19095-Q04, $30 \mathrm{~m}$ length, $0.530 \mathrm{~mm}$ I.D.) and HPMolesieve (19095P-MSO, $30 \mathrm{~m}$ length, $0.530 \mathrm{~mm}$ I.D.), equipped with thermal conductivity and flame ionization detectors.

Liquid products were analyzed via a combination of GC and MS. The instrument used was a 7890A/5975C triple-axis detector diffusion pump based GC-MS equipped with split/splitless inlet (Agilent Technologies, Santa Clara, CA, USA). Chromatographic separation was achieved by a $30 \mathrm{~m} \times 250 \mu \mathrm{m}$ HP-5MS (5\% phenyl, 95\% methylpolysiloxane) capillary column with film thickness of $0.25 \mu \mathrm{m}$. He 5.0 (99.999\%) was used as carrier gas in a constant flow rate mode $(1 \mathrm{~mL} / \mathrm{min})$. The oven temperature program was set at $35^{\circ} \mathrm{C}$ for $5 \mathrm{~min}$, increased by $10^{\circ} \mathrm{C} / \mathrm{min}$ to $250{ }^{\circ} \mathrm{C}$ and held at $250^{\circ} \mathrm{C}$ for $10 \mathrm{~min}$. The temperature of the split/splitless injector was $280{ }^{\circ} \mathrm{C}$ and the volume of the samples injected was $1 \mu \mathrm{L}$ with a split ratio of 100:1 using an ultra-inert liner with glass wool (Agilent Technologies). The temperatures of the ion source, the quadrupole and the MS interface for both instruments were 230, 150 and $250{ }^{\circ} \mathrm{C}$, respectively. Both full scan $(40-160 \mathrm{~m} / \mathrm{z})$ and selective ion monitoring modes were performed under electron impact ionization mode at $70 \mathrm{eV}$. The quantification of compounds carried out by an internal standard method using 2-butanol to monitor batch reproducibility and to correct for variations that occurred during sample preparation and analysis. Mass selective detector ChemStation software (Agilent Technologies) was used to acquire mass spectrometric data. The mass spectra of all detected compounds were compared with spectra in the National Institute of Standards and Technology library. The following ions were chosen for quantification: glycerol (61), acetol (74), acetone (58), acrolein (56), allyl alcohol (57), acetaldehyde (44) and acetic acid (60).

\subsection{Reaction metrics}

The catalysts' performance in the gas phase is reported in terms of $\mathrm{H}_{2}$ yield, $\mathrm{H}_{2}, \mathrm{CO}, \mathrm{CH}_{4}$ and $\mathrm{CO}_{2}$ selectivities, glycerol conversion into gaseous products, and total glycerol conversion. The liquid phase performance is reported in terms of acetol $\left(\mathrm{C}_{3} \mathrm{H}_{6} \mathrm{O}_{2}\right)$, acetone $\left(\left(\mathrm{CH}_{3}\right)_{2} \mathrm{CO}\right)$, allyl alcohol $\left(\mathrm{CH}_{2}=\mathrm{CHCH}_{2} \mathrm{OH}\right)$, acetaldehyde $\left(\mathrm{C}_{2} \mathrm{H}_{4} \mathrm{O}\right)$, acrolein $\left(\mathrm{C}_{3} \mathrm{H}_{4} \mathrm{O}\right)$ and acetic acid $\left(\mathrm{C}_{2} \mathrm{H}_{4} \mathrm{O}\right)$ selectivities. Performance parameters were calculated based on the following equations:

Total glycerol conversion $=\frac{\text { Glycerol }_{\text {in }}-\text { Glycerol }_{\text {out }}}{\text { Glycerol }_{\text {in }}} \times 100 \%$ 
Glycerol conversion into gaseous products $=$

$$
\begin{array}{r}
\frac{\mathrm{C} \text { atoms in the gas products }}{\text { Total } \mathrm{C} \text { atoms in the feedstock }} \times 100 \% \\
\mathrm{H}_{2} \text { yield }=\frac{\mathrm{H}_{2} \text { moles produced }}{\text { moles of glycerol in the feedstock }} \times 100 \% \\
\mathrm{H}_{2} \text { selectivity }=\frac{\mathrm{H}_{2} \text { moles produced }}{\mathrm{C} \text { atoms produced in the gas products }} \times \frac{1}{\mathrm{RR}} \times 100 \%
\end{array}
$$

where RR is the reforming ratio $(7 / 3)$, defined as the ratio of moles of $\mathrm{H}_{2}$ to $\mathrm{CO}_{2}$ formed.

$$
\text { Selectivity of } i=\frac{C \text { atoms in species } i}{\mathrm{C} \text { atoms produced in the gas phase }} \times 100 \%
$$

where species $i$ refers to $\mathrm{CO}, \mathrm{CO}_{2}$ or $\mathrm{CH}_{4}$.

$$
\text { Selectivity of } i^{\prime}=\frac{\mathrm{C} \text { atoms in species } i^{\prime}}{\mathrm{C} \text { atoms produced in the liquid phase }} \times 100 \%
$$

where species $i$ ' refers to acetol, acetone, allyl alcohol, acetaldehyde or acetic acid.

\section{Results and discussion}

\subsection{Characterization results}

\subsubsection{Physicochemical properties of catalysts}

Chemical and structural properties of the calcined and reduced $\mathrm{Ni} / \mathrm{Al}$ samples, including nickel content and the nickel species particle size, have been presented previously [23]. The $\mathrm{N}_{2}$ adsorption-desorption isotherms and the pore size distribution curves of the calcined and reduced samples are shown in Fig. 2(a) and (b), respectively. The BJH adsorption data were used to establish the pore size distribution curves. The isotherms for all samples are type IVa with a hysteresis loop, indicating the presence of mesopores. The adsorption behavior in mesopores is determined by the adsorbent-adsorptive interactions and by the interactions between the molecules in the condensed state. The initial monolayer-multilayer adsorption on the mesopore walls, which takes the same path as the corresponding part of a Type II isotherm, is followed by pore condensation. Pore condensation is the phenomenon whereby a gas condenses to a liquid-like phase in a pore at a pressure less than the saturation pressure of the bulk liquid. A typical feature of type IV isotherms is a final saturation plateau of variable length (sometimes present as a mere inflexion point). Capillary condensation is accompanied by hysteresis, especially for Type IVa isotherms [26]. This occurs when the pore width exceeds a certain critical width, which is dependent on the adsorption system and temperature (e.g., for nitrogen and argon adsorption in cylindrical pores at -196 and $-186^{\circ} \mathrm{C}$, respectively, hysteresis starts to occur for pores wider than $\sim 4 \mathrm{~nm}$ ). The hysteresis loop is $\mathrm{H} 2$ type, indicating pore connectivity with ink-bottle or channel-like pores.

The pore size distribution curves depict that all samples were single modal type with the mesopore range centered around $10-20 \mathrm{~nm}$. The pore distribution curve of the calcined sample of Ni/Al-iwi is relatively broad, while the $\mathrm{Al}, \mathrm{Ni} / \mathrm{Al}$-wet and Ni/Al-edf calcined samples curves are sharper. For the reduced samples, $\mathrm{Ni} / \mathrm{Al}$-iwi has a quite broad curve, $\mathrm{Ni} / \mathrm{Al}$-edf has a sharp curve, with the $\mathrm{Ni} / \mathrm{Al}$-wet curve somewhere in between. No micropore volume was measured by the $t$-plot method, indicating that only mesopores developed for all of the samples.

These results provide an indication of the different mechanisms by which nickel species are deposited on the alumina surface, depending on the catalyst preparation process. After calcination the Ni/Al-wet and Ni/Al-edf samples seem to have quite similar textural properties, while this is not true for the same catalysts after their reduction. The Ni/Al-iwi exhibits a quite different texture, with wider pores with a narrower size distribution after reduction. It seems that for the former catalysts, the deposition occurred as a more uniform covering of the mesopores' internal surface with small nickel particles.

Textural properties of calcined and reduced samples, including the SSA, $V_{\mathrm{p}}$ and $D_{\mathrm{a}}$, are presented in Table 1 . The SSA of the calcined support decreased considerably, the $D_{\mathrm{a}}$ doubled and the $V_{\mathrm{p}}$ remained approximately the same (commercial alumina has a SSA of $281 \mathrm{~m}^{2} / \mathrm{g}, D_{\mathrm{a}}$ of $7.8 \mathrm{~nm}$ and $V_{\mathrm{p}}$ of 0.65 $\mathrm{mL} / \mathrm{g}$ ). These occurrences can probably be attributed to thermal sintering. A partial change in the crystalline structure of the alumina from $\gamma$ to a tetragonally distorted defective spinel alumina similar to $\delta-\mathrm{Al}_{2} \mathrm{O}_{3}$ or $\gamma^{\prime}-\mathrm{Al}_{2} \mathrm{O}_{3}$ cannot be discounted
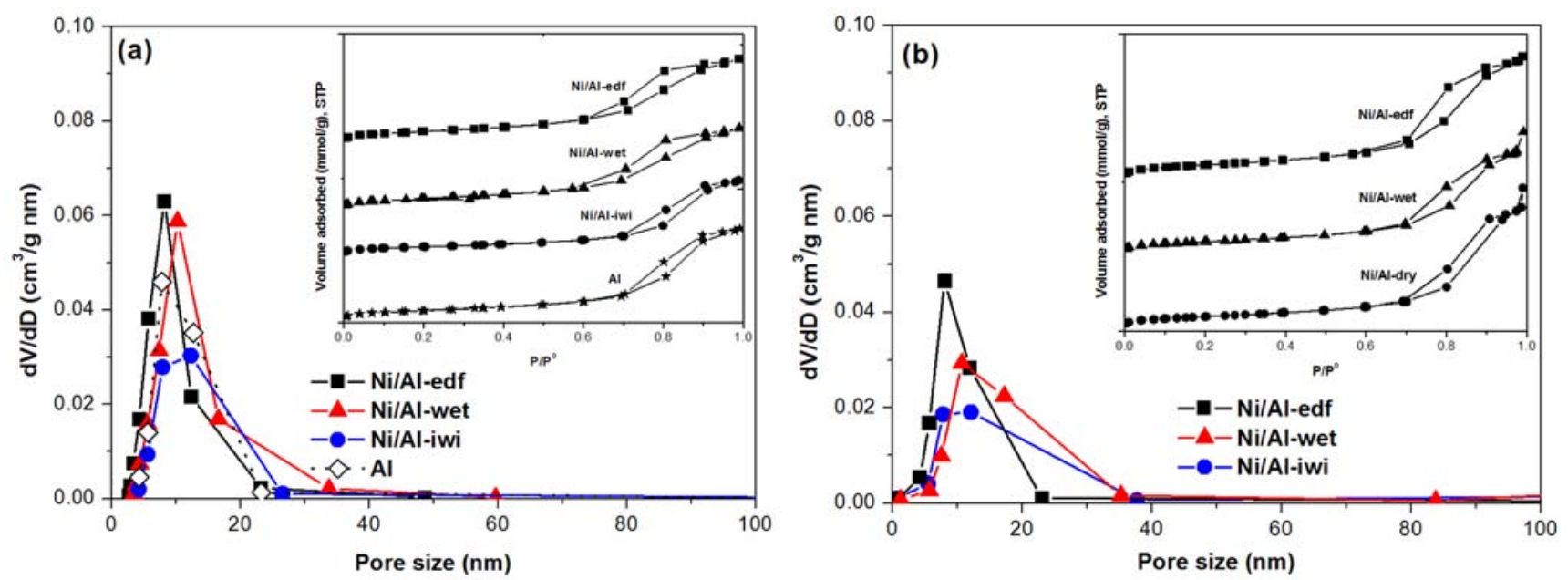

Fig. 2. $\mathrm{N}_{2}$ adsorption-desorption isotherms (inset) and the pore size distribution of the calcined catalysts and alumina (a), and reduced catalysts (b). 
$[27,28]$. However, this partial transformation was not detected by XRD analysis. The nickel species deposition resulted in a further decrease in the BET surface area values for the calcined catalyst samples (the smallest drop was recorded for the $\mathrm{Ni} / \mathrm{Al}$-edf), while $V_{\mathrm{p}}$ dropped almost equally for all samples (Table 1). The $D_{\mathrm{a}}$ decreased for the Ni/Al-edf and increased for the Ni/Al-wet and Ni/Al-iwi samples. A decrease in the $\mathrm{D}_{\mathrm{a}}$ following nickel loading shows that most of the pores are still available (i.e., little pore blockage), which is an indication of good dispersion of nickel species on the alumina's surface.

A different trend can be seen between the reduced $\mathrm{Ni} / \mathrm{Al}$-edf and the other two reduced samples (Table 1). Specifically, the reduction resulted in an increase to the SSA for $\mathrm{Ni} / \mathrm{Al}$-edf and a decrease to the $V_{\mathrm{p}}$ values, while the $D_{\mathrm{a}}$ value slightly increased (from 10.90 to $12.52 \mathrm{~nm}$ ). Opposite effects were observed for the Ni/Al-wet and Ni/Al-iwi samples; for these catalysts, SSA values decreased, and $V_{\mathrm{p}}$ and $D_{\mathrm{a}}$ values increased. The differences in the edf sample indicate stability to the reduction treatment, possibly because the $\mathrm{pH}$ and ionic strength were kept constant during the preparation of this catalyst. The increase in the pore size can be explained by a combination of the reduction degree of the $\mathrm{Ni}$ oxide species on the catalytic surfaces, structural shrinkage and blockage of pores at higher temperatures during the reduction process.

\subsection{2. $X R D$}

The degree of crystallinity and the phases of the prepared catalysts were identified for their calcined and reduced forms by XRD analysis (Fig. 3). The characteristic peaks of $\gamma-\mathrm{Al}_{2} \mathrm{O}_{3}$ were detected for all samples at $2 \theta=37.7^{\circ}, 45.9^{\circ}$ and $67.0^{\circ}$. There is a small increase in $\gamma-\mathrm{Al}_{2} \mathrm{O}_{3}$ in the calcined samples with a characteristic peak intensity at $2 \theta=45.9^{\circ}$. This can be attributed to an overlapping with the nickel aluminate $\left(\mathrm{NiAl}_{2} \mathrm{O}_{4}\right)$ phase's characteristic peak at $2 \theta=46^{\circ}$. The formation of the spinel $\mathrm{NiAl}_{2} \mathrm{O}_{4}$ phase, observed at the diffraction lines $2 \theta=$ $19.0^{\circ}, 32.0^{\circ}, 37.0^{\circ}$ and $59.6^{\circ}$, is caused by the reaction between nickel oxide $(\mathrm{NiO})$ and $\mathrm{Al}_{2} \mathrm{O}_{3}$ at high calcination temperature $[14,25]$. $\mathrm{NiAl}_{2} \mathrm{O}_{4}$ crystallizes in the cubic system, while the framework of the spinel structures consists of an ensemble of tetrahedral and octahedral coordination occupied by bivalent $\left(\mathrm{Ni}^{2+}\right)$ and trivalent $\left(\mathrm{Al}^{3+}\right)$ cations, respectively. This distribution can change in the cases where an octahedral site is partially adopted by the $\mathrm{Ni}^{2+}$ ions and the tetrahedral site hosts both $\mathrm{Al}^{3+}$ and the $\mathrm{Ni}^{2+}$ ions. Thus, a family of compounds with inverse spinel structure, described as $\mathrm{Ni}_{1-x}\left[\mathrm{Ni}_{x} \mathrm{Al}_{2-x}\right] \mathrm{O}_{4}(0<x<1)$, can be generated by this structural flexibility $[18,20]$.

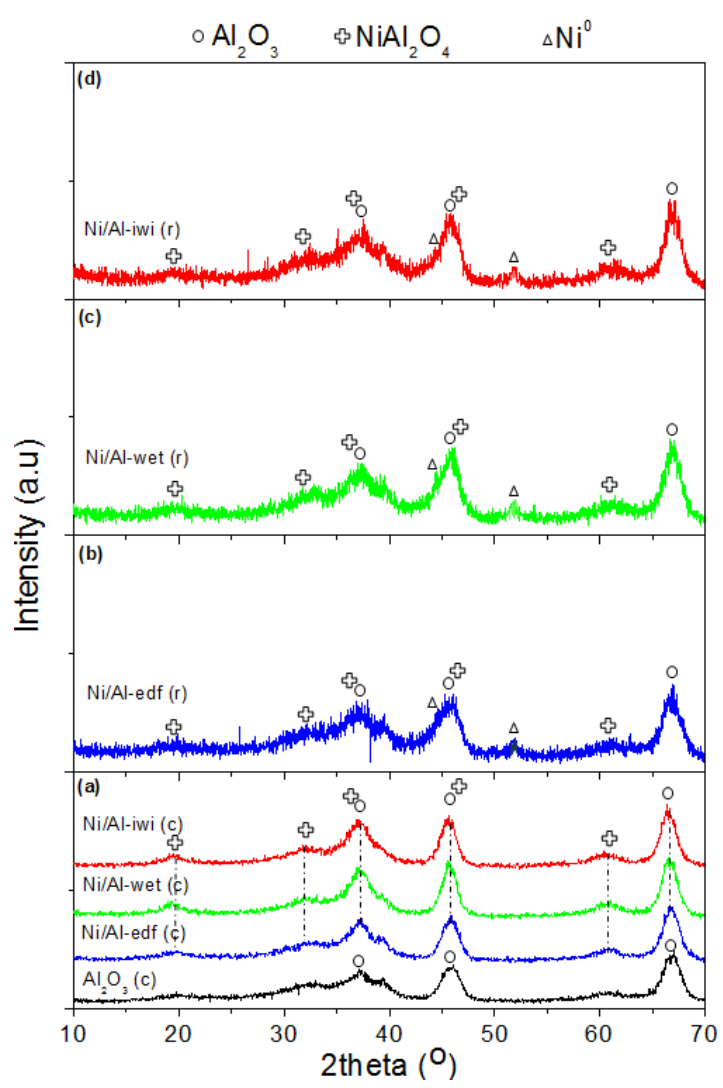

Fig. 3. XRD patterns of calcined and reduced Ni/Al samples.

The absence of the NiO structure can be either related to the size of these structures (i.e., they are smaller than 2-7 nm, which is the typical XRD detection limit [29]), or that the structures are nearly amorphous [23]. Note that $\mathrm{NiO}$ was indicated by the TEM results for the calcined samples (see below). Two major differences can be observed between the calcined and reduced samples: the first is the decreasing intensities of $\mathrm{Al}_{2} \mathrm{O}_{3}$ and $\mathrm{NiAl}_{2} \mathrm{O}_{4}$; the second difference is the appearance of small peaks because of the presence of metallic nickel $\left(\mathrm{Ni}^{0}\right)$, indicated by peaks at $2 \theta=44^{\circ}$ and $51.2^{\circ}$. The low intensity of the $\mathrm{Ni}^{0}$ peaks is correlated to the small size of the metallic nickel species $[30,31]$.

\subsection{3. $T P R$}

TPR measurements were carried out to examine the interaction between nickel species and the support in the Ni/Al-edf, $\mathrm{Ni} / \mathrm{Al}$-wet and Ni/Al-iwi catalysts. A Gaussian-type deconvolution was applied in order to characterize the type of reducible

Table 1

Textural properties of calcined and reduced samples.

\begin{tabular}{lcccc}
\hline Sample * & $\begin{array}{c}\text { BET surface area } \\
\left(\mathrm{m}^{2} / \mathrm{g}\right)\end{array}$ & $\begin{array}{c}\text { Pore volume } V_{\mathrm{p}} \\
\left(\mathrm{cm}^{3} / \mathrm{g}\right)\end{array}$ & $\begin{array}{c}\text { Adsorption average pore } \\
\text { width } D_{\mathrm{a}}(\mathrm{nm})\end{array}$ & $\begin{array}{c}\text { BJH adsorption average pore } \\
\text { width }(\mathrm{nm})\end{array}$ \\
\hline $\mathrm{Al}_{2} \mathrm{O}_{3}$ (c) & $197.4 \pm 0.27$ & 0.6565 & 13.30 & $\begin{array}{c}\text { BJH desorption average } \\
\text { pore width }(\mathrm{nm})\end{array}$ \\
$\mathrm{Ni} /$ Al-edf (c) & $172.5 \pm 0.14$ & 0.6010 & 11.07 & 9.09 \\
$\mathrm{Ni} /$ Al-edf (r) & $177.1 \pm 0.11$ & 0.5889 & 12.52 & 9.30 \\
$\mathrm{Ni} /$ Al-wet (c) & $162.9 \pm 0.06$ & 0.5827 & 14.10 & 9.28 \\
$\mathrm{Ni} /$ Al-wet (r) & $158.6 \pm 0.14$ & 0.7236 & 15.77 & 11.33 \\
$\mathrm{Ni} /$ Al-iwi (c) & $157.9 \pm 0.30$ & 0.5907 & 14.07 & 12.43 \\
$\mathrm{Ni} /$ Al-iwi (r) & $156.3 \pm 0.13$ & 0.6664 & 17.06 & 11.81 \\
\hline
\end{tabular}

${ }^{*} \mathrm{c}=$ calcined, $\mathrm{r}=$ reduced. 
nickel species present on the various catalysts (Fig. 4). All catalysts exhibited a small peak at low temperature, attributed to the reduction of bulk $\mathrm{NiO}$ phase ( $\alpha$-peak) and a broad reduction band corresponding to the nickel aluminate structures $(\beta$ - and $\gamma$-peaks), indicated strong interaction between nickel species and the alumina support. These results are consistent with the XRD results (Fig. 3), showing the existence of the nickel aluminate phase for all catalysts were free of $\alpha$-NiO species.

In the case of the $\mathrm{Ni} / \mathrm{Al}$-iwi catalyst, the characteristic reduction peak attributed to bulk $\mathrm{NiO}$ is negligible, while the deconvolution curves' peaks were located at $652^{\circ} \mathrm{C}(\beta$-peak) and $747^{\circ} \mathrm{C}(\gamma$-peak). Both the $\beta$ - and $\gamma$-peaks were located at quite lower temperatures for the $\mathrm{Ni} / \mathrm{Al}$-wet and $\mathrm{Ni} / \mathrm{Al}$-edf catalysts, 615 and $712{ }^{\circ} \mathrm{C}$, respectively. The contribution of $\beta$ - and $\gamma$-peaks to the observed reduction peaks, as well as their position, could relate to the different $\mathrm{Ni}^{2+}$ coordination in the spinel framework. The contributions of the $\beta$-peaks, estimated from the deconvolution curves, in the total $\mathrm{Ni}$ species present in the spinel structure of the $\mathrm{Ni} / \mathrm{Al}$-iwi, Ni/Al-wet and $\mathrm{Ni} / \mathrm{Al}$-edf catalysts were $53.5 \%, 67.8 \%$ and $76.4 \%$, respectively.

The contribution of the $\beta$-peak in the Ni/Al-edf catalyst was higher than in the other two catalysts, indicating that the nickel aluminate species in Ni/Al-edf were more reducible. The surface nickel aluminate phase has a high degree of nickel-saturation, which is more reducible than that with a low degree of nickel-saturation [32,33]. This is because reduction of nickel species is favored when nickel species are surrounded by less aluminum species, which act as electron deficient sites. The retention of more nickel-saturated surface nickel aluminate phase by the Ni/Al-edf catalyst, in comparison with the other two samples, is another indication that the edf preparation method was more effective in the formation of finely dispersed nickel species in the alumina support.

\subsubsection{Electron microscopy}

TEM identified $\mathrm{Ni} / \mathrm{Al}_{2} \mathrm{O}_{4}$ and $\mathrm{NiO}$ phases for the calcined samples. Metallic nickel was identified in the reduced catalysts,

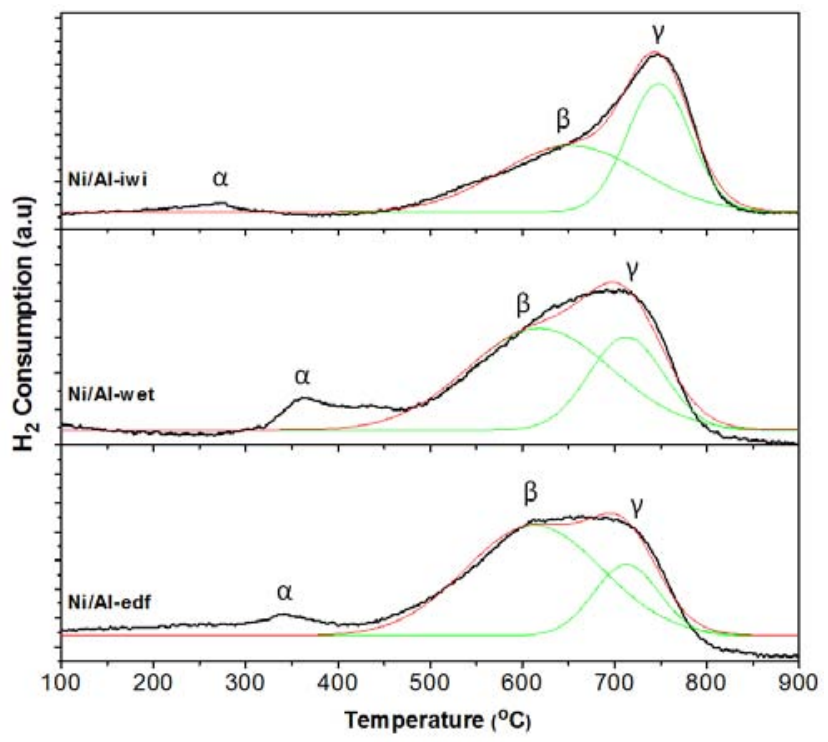

Fig. 4. TPR profiles deconvolution of $\mathrm{Ni} / \mathrm{Al}$ samples. while $\mathrm{NiO}$ was absent. TEM experiments confirmed that the particle size of the Ni/Al-edf catalyst was slightly lower than the other catalysts. TEM images of the catalysts, as well as a more detailed discussion regarding these results, can be found in a previous publication by our group [23].

The SEM technique was also used to examine the catalysts' surface texture and morphology. The SEM images of the calcined Ni/Al-wet catalyst are shown in Fig. 5(a), while Fig. 5(b) shows the same catalyst after reaction (used sample). The calcined catalyst is of nonuniform morphology and includes large ensembles and micro- and nanoparticles.

\subsection{Catalytic activity and selectivity}

\subsubsection{Glycerol conversion}

Fig. 6 shows the dependence of reaction temperature on the total glycerol conversion (Fig. 6(a)) and glycerol conversion into gaseous products (Fig. 6(b)). Total glycerol conversion values range from $80 \%\left(400-500{ }^{\circ} \mathrm{C}\right)$ to $90 \%\left(550-750{ }^{\circ} \mathrm{C}\right)$ for all the catalysts. The conversion of glycerol into gaseous products drastically increases at $400-600{ }^{\circ} \mathrm{C}$, reaching maxima of $90 \%$ at $600{ }^{\circ} \mathrm{C}$ and remaining stable up to $750{ }^{\circ} \mathrm{C}$ for the $\mathrm{Ni} / \mathrm{Al}$-edf and Ni/Al-iwi catalysts. The Ni/Al-edf and Ni/Al-wet catalysts had an almost identical and superior activity in the low temperature range $\left(400-550^{\circ} \mathrm{C}\right)$ compared with $\mathrm{Ni} / \mathrm{Al}$-iwi. The Ni/Al-edf and Ni/Al-iwi samples seem to have an improved ability to convert glycerol into gaseous products at higher temperatures.

Blank tests using the same reaction feed and either an empty reactor tube or calcined $\mathrm{Al}_{2} \mathrm{O}_{3}$ particles have also been conducted (Fig. 6(a) and (b)). The trend observed for the blank reactions is similar to that observed for the catalytic samples, with lower conversion values-about $10 \%$ for the calcined $\mathrm{Al}_{2} \mathrm{O}_{3}$ and $20 \%$ for the homogenous (empty tube) reaction-for the whole temperature range, compared with the Ni catalysts. The only exception to this is observed at very low temperature values of $400-450{ }^{\circ} \mathrm{C}$, where conversions in the empty reactor are about half those seen in the catalytic reactions. Previous work indicated that at reaction temperatures above $600{ }^{\circ} \mathrm{C}$, considerable homogenous conversion values could be achieved, while $\mathrm{H}_{2}, \mathrm{CO}_{2}$, $\mathrm{CO}$ and $\mathrm{CH}_{4}$ were the main products of the GSR $[3,11]$.

The cleavage of the $\mathrm{C}-\mathrm{C}$ or $\mathrm{C}-\mathrm{O}$ bonds of glycerol can only be achieved through a dehydrogenation step taking place on the metal active sites and the production of intermediates on the

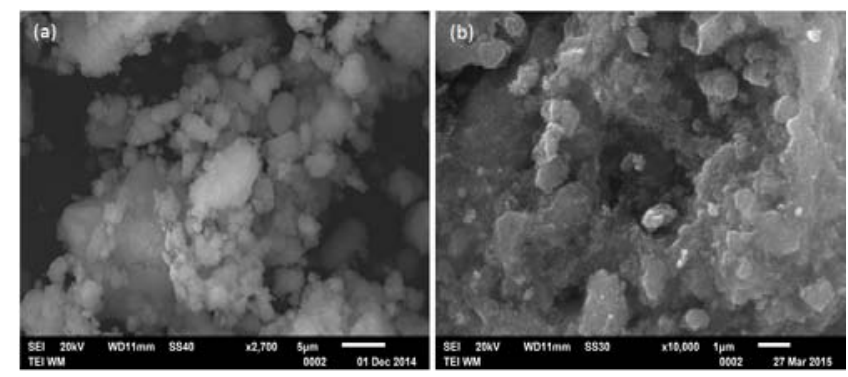

Fig. 5. SEM images with different magnifications of Ni/Al-wet catalyst. (a) Calcined sample; (b) Used sample. 

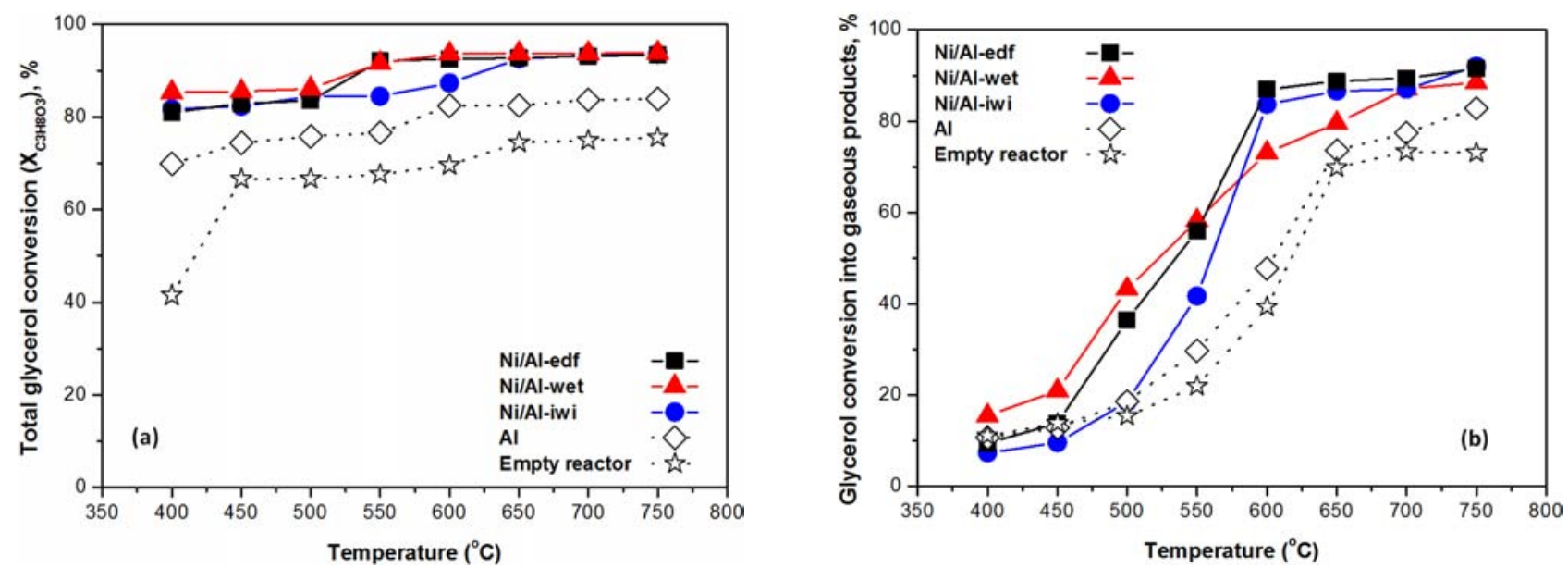

Fig. 6. Total conversion (a) and glycerol conversion into gaseous products (b). Reaction conditions: $\mathrm{C}_{3} \mathrm{H}_{8} \mathrm{O}_{3}\left(20\right.$ wt $\%$ ) $/ \mathrm{H}_{2} \mathrm{O}$ (total liquid flow rate $=$ $0.12 \mathrm{~mL} / \mathrm{min}) / \mathrm{He}(38 \mathrm{~mL} / \mathrm{min}), w_{\text {catalyst }}=200 \mathrm{mg}, T=400-750{ }^{\circ} \mathrm{C}$.

catalytic surface [6,12]. The formation of $\mathrm{CO}$ and $\mathrm{H}_{2}$ is mainly because of the strong $\mathrm{C}-\mathrm{C}$ bond breaking capacity of nickel catalysts. The steam reforming (SR) reaction is limited at low temperatures from a thermodynamic point of view, while the WGS and methanation reactions are favored. A higher contribution of the GSR, compared with glycerol decomposition at higher temperatures, is also suggested by our results.

The improved catalytic activity for gaseous products of $\mathrm{Ni} / \mathrm{Al}$-edf can be attributed to the surface $\mathrm{NiAl}_{2} \mathrm{O}_{4}$ [32-36]. Most likely, the active sites of the Ni/Al-edf catalyst are dynamically evolved as the reaction progresses. At the beginning of the reaction nickel particles exist on the catalyst surface as a mixture of small, free particles and encapsulated by a porous $\mathrm{NiO} / \mathrm{NiAl}_{2} \mathrm{O}_{4}$ layer [21]. This could explain the higher glycerol conversion into gaseous products and confirm that the type of active sites can affect catalyst's activity and selectivity for the GSR by favoring different reaction pathways.

\subsubsection{Hydrogen yield and selectivity}

The influence of reaction temperature on hydrogen yield $\left(Y_{\mathrm{H} 2}\right)$ and selectivity $\left(\mathrm{S}_{\mathrm{H} 2}\right)$ is shown in Fig. 7. Both values increase with increasing temperature and it is well known that
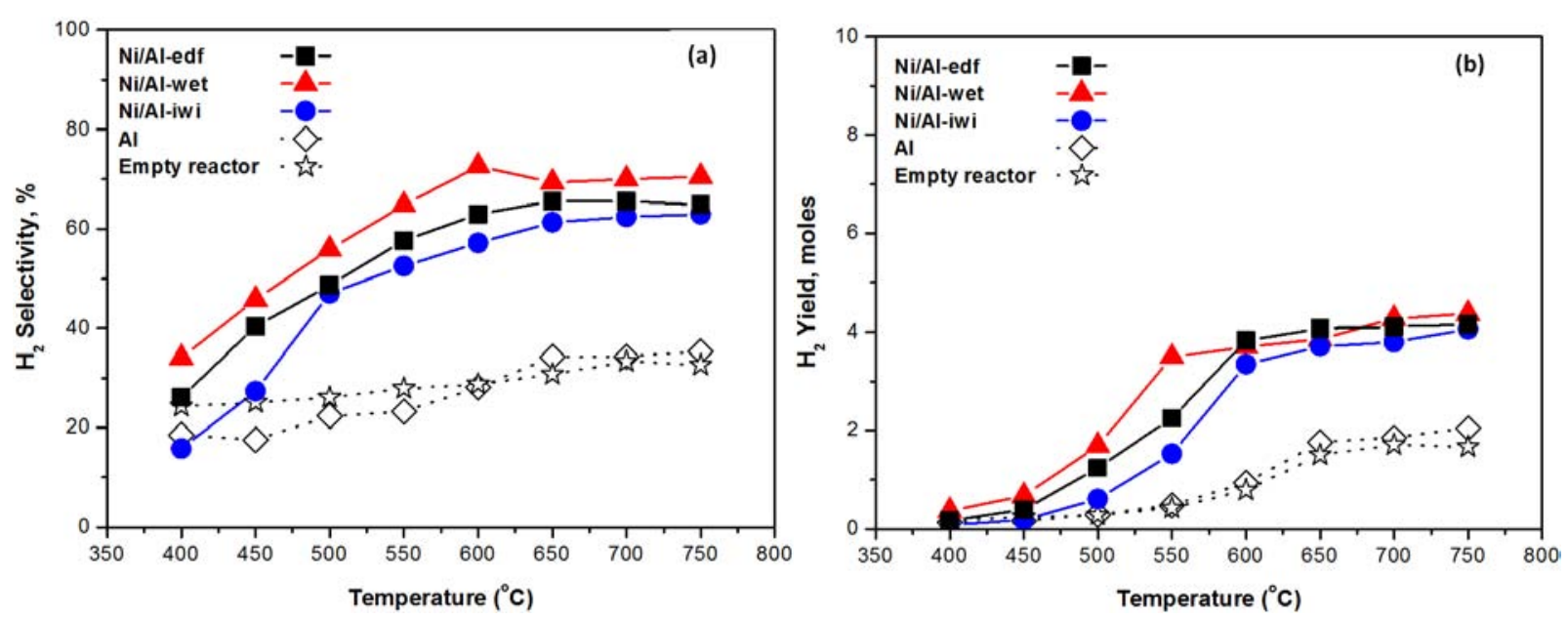

Fig. 7. Hydrogen selectivity (a) and yield (b). Reaction conditions: $\mathrm{C}_{3} \mathrm{H}_{8} \mathrm{O}_{3}(20 \mathrm{vol} \%) / \mathrm{H}_{2} \mathrm{O}$ (total liquid flow rate $\left.=0.12 \mathrm{~mL} / \mathrm{min}\right) / \mathrm{He}(38 \mathrm{~mL} / \mathrm{min}$ ), $W_{\text {catalyst }}=200 \mathrm{mg}, T=400-750^{\circ} \mathrm{C}$. temperature significantly affects the hydrogen equilibrium concentrations [37]. The molar fraction and molar flow of hydrogen produced increase when the operating reaction temperatures are raised [38]. A similar trend has also been observed when other fuels are utilized for hydrogen production, such as methane, methanol and ethanol [39]. According to Wang et al. [1], the reaction with a water to glycerol feed ratio (WGFR) equal to 9 is expected to give the greatest quantity of hydrogen $(6 \mathrm{~mol})$ at $652{ }^{\circ} \mathrm{C}$. Increasing the WGFR in the feed over this ratio in our system steadily increased the production of hydrogen. The enhancement of hydrogen production has been observed for all cases of SR reactions when excess steam has been used to overcome equilibrium limitations [40].

Comparison between our catalysts' experimental results (Fig. 7(b)) reveals that their $\mathrm{H}_{2}$ yield values are quite different for low reaction temperatures $\left(400-600{ }^{\circ} \mathrm{C}\right)$, with the trend $Y_{\mathrm{H} 2}$ (Ni/Al-wet) $>Y_{\mathrm{H} 2}\left(\mathrm{Ni} / \mathrm{Al}\right.$-edf) $>Y_{\mathrm{H} 2}\left(\mathrm{Ni} / \mathrm{Al}\right.$-iwi). The $Y_{\mathrm{H} 2}$ values are almost identical for all the catalysts at higher temperatures $\left(600-750{ }^{\circ} \mathrm{C}\right)$, reaching a value of 4.4 hydrogen moles. The $\mathrm{H}_{2}$ selectivity (Fig. 7(a)) of the catalysts also seems to follow the aforementioned trend for the whole temperature range, reaching the values of $71 \%, 65 \%$ and $63 \%$ for NiAl-wet, NiAl-edf and

Werast $=200 \mathrm{mg}, \mathrm{T}=400-750^{\circ} \mathrm{C}$ 
NiAl-iwi, respectively. The $Y_{\mathrm{H} 2}$ and $S_{\mathrm{H} 2}$ for the empty reactor and with calcined $\mathrm{Al}_{2} \mathrm{O}_{3}$ are almost identical for the whole reaction temperature range, reaching the values of $35 \%$ and 2 moles at $650-750^{\circ} \mathrm{C}$, respectively.

As already mentioned, the GSR should be considered as a combination of the glycerol pyrolysis as the primary reaction and the WGS as the secondary reaction. The water in the reactor's inlet mixture provides the proper dilution to produce syngas, resulting in higher conversions [9]. The enhanced glycerol conversion and hydrogen selectivity evident in our experimental results is expected based on previous literature $[2,41]$, with the values increasing with increased steam to carbon $(\mathrm{S} / \mathrm{C})$ molar ratio in the feed.

\subsubsection{Gaseous product selectivity}

The influence of reaction temperature on the gaseous product selectivities of $\mathrm{CO}_{2}\left(S_{\mathrm{CO} 2}\right), \mathrm{CO}\left(S_{\mathrm{CO}}\right)$ and methane $\left(S_{\mathrm{CH} 4}\right)$ is presented in Fig. 8. A different trend can be observed for $S_{\mathrm{CH} 4}$ with increasing temperature for the homogenous and calcined $\mathrm{Al}_{2} \mathrm{O}_{3}$ experiments versus the catalytic reactions (Fig. 8(a)). The $\mathrm{S}_{\mathrm{CH} 4}$ is almost zero for the homogeneous experiments at low reaction temperatures $\left(400-550{ }^{\circ} \mathrm{C}\right)$, increases with temperature $\left(T>550^{\circ} \mathrm{C}\right)$ and reaches a plateau of $28 \%$ for higher temperatures $\left(650-750{ }^{\circ} \mathrm{C}\right) . S_{\mathrm{CH} 4}$ decreases with increasing temperature in the catalytic reactions and approaches zero at 600 ${ }^{\circ} \mathrm{C}$. Methane SR is accelerated in the presence of the catalysts with increasing temperature and contributes to the formation of $\mathrm{H}_{2}$. The formation of $\mathrm{CH}_{4}$ is almost nil with high WGFRs, as in our case, and at higher temperatures $\left(>650{ }^{\circ} \mathrm{C}\right)$. According to the thermodynamic analysis of Adhikari et al. [41], the production of water and methane decreases as the reaction temperature increases, while the amounts of $\mathrm{CO}, \mathrm{CO}_{2}$ and $\mathrm{H}_{2}$ increase; this can be attributed to methane SR.

The $S_{\text {co }}$ seems to be quite constant (70\%) with temperature for the homogenous and calcined $\mathrm{Al}_{2} \mathrm{O}_{3}$ experiments (Fig. 8(b)). The $S_{\mathrm{CO} 2}$ remains unaffected with increasing temperature between $400-500{ }^{\circ} \mathrm{C}$, drastically decreases from $30 \%$ to $10 \%$ between $500-650{ }^{\circ} \mathrm{C}$ and remains constant between $650-750$ ${ }^{\circ} \mathrm{C}$ (Fig. 8(c)).

The $S_{\mathrm{Co}}$ increases with increasing temperature for all catalysts, reaching a plateau at $600-750{ }^{\circ} \mathrm{C}$, with values of $79 \%$, $67 \%$ and $56 \%$ for the $\mathrm{Ni} / \mathrm{A}$-iwi, $\mathrm{Ni} / \mathrm{Al}$-edf and $\mathrm{Ni} / \mathrm{Al}$-wet catalysts, respectively (Fig. 8(b)). The opposite trend was observed for the $S_{\mathrm{CO} 2}$ (Fig. 8(c)), which decreases with temperature over the low temperature range $\left(<600{ }^{\circ} \mathrm{C}\right)$ and then remains almost unaffected until $750{ }^{\circ} \mathrm{C}$, with values of $47 \%, 34 \%$ and $22 \%$ for $\mathrm{Ni} / \mathrm{Al}-$ wet, Ni/Al-edf and Ni/A-iwi, respectively. These observations can be explained by the varying degree of the reverse WGS participating in the whole process reaction pathway for each one of our catalysts, which are strongly dependent on the synthesis method of the catalysts and their individual characteristics.

High production of $\mathrm{CO}$ and $\mathrm{CH}_{4}$ can be associated with the decomposition of acetaldehyde $\left(\mathrm{CH}_{3} \mathrm{CHO} \rightarrow \mathrm{CH}_{4}+\mathrm{CO}\right)$, which has formed as an intermediate product through the glycerol dehydrogenation reaction by a radical decomposition mechanism. Low $\mathrm{CO}_{2}$ production could be attributed to the fact that the WGS reaction does not occur and there is not enough $\mathrm{H}_{2}$ to allow the dehydrogenation reaction [10].

The comparison between catalysts shows that the synthesis method influences their $S_{\mathrm{CO}}$ and $S_{\mathrm{CO} 2}$, as their values are quite different for reaction temperatures higher than $500{ }^{\circ} \mathrm{C}$. Specifically, the $S_{\mathrm{Co}}$ and $S_{\mathrm{CO} 2}$ seem to be rather stable for the temperature range $600-750{ }^{\circ} \mathrm{C}$, with values of $79 \%$ and $22 \%$ for $\mathrm{Ni} / \mathrm{Al}-\mathrm{iwi}, 67 \%$ and $34 \%$ for $\mathrm{Ni} / \mathrm{Al}$-edf and $56 \%$ and $47 \%$ for $\mathrm{Ni} /$ Al-wet, respectively.

The influence of reaction temperature on the $\mathrm{H}_{2} / \mathrm{CO}$ and the $\mathrm{CO} / \mathrm{CO}_{2}$ molar ratios is presented in Fig. 9. The $\mathrm{H}_{2} / \mathrm{CO}$ molar ratio is almost identical for the homogenous and calcined $\mathrm{Al}_{2} \mathrm{O}_{3}$ experiments and slightly increases with temperature from 0.58 $\left(400{ }^{\circ} \mathrm{C}\right)$ to $1.43\left(750{ }^{\circ} \mathrm{C}\right)$. The $\mathrm{CO} / \mathrm{CO}_{2}$ molar ratio increases with increasing temperature for $T<650{ }^{\circ} \mathrm{C}$ and decreases between $650-750{ }^{\circ} \mathrm{C}$. Maximum values were obtained at $650{ }^{\circ} \mathrm{C}$ and were about $5.34\left(\mathrm{H}_{2} / \mathrm{CO}\right)$ and $10.46\left(\mathrm{CO} / \mathrm{CO}_{2}\right)$ for both calcined $\mathrm{Al}_{2} \mathrm{O}_{3}$ and empty reactor experiments.

The $\mathrm{H}_{2} / \mathrm{CO}$ molar ratio increases with increasing temperature for all catalysts reaching values of 3.35, 2.73 and 2.03 for $\mathrm{Ni} / \mathrm{Al}$-wet, Ni/Al-edf and Ni/Al-iwi, respectively, at $750{ }^{\circ} \mathrm{C}$ (Fig. 9 (a) and (b)). The $\mathrm{CO} / \mathrm{CO}_{2}$ molar ratio trend is quite different for the catalysts; the ratio remains almost stable for the whole temperature range at 1.45 for $\mathrm{Ni} / \mathrm{Al}$-wet and reaches a peak at $650{ }^{\circ} \mathrm{C}$ for $\mathrm{Ni} / \mathrm{Al}$-edf and $\mathrm{Ni} / \mathrm{Al}$-iwi with values of 2.21 and 3.66, respectively. This may indicate the presence of carbon deposits that may also react with the $\mathrm{CO}_{2}$ formed according to the Boudouard reaction, altering the $\mathrm{CO} / \mathrm{CO}_{2}$ molar ratio as the reaction proceeds and the catalyst deactivates. It must be concluded
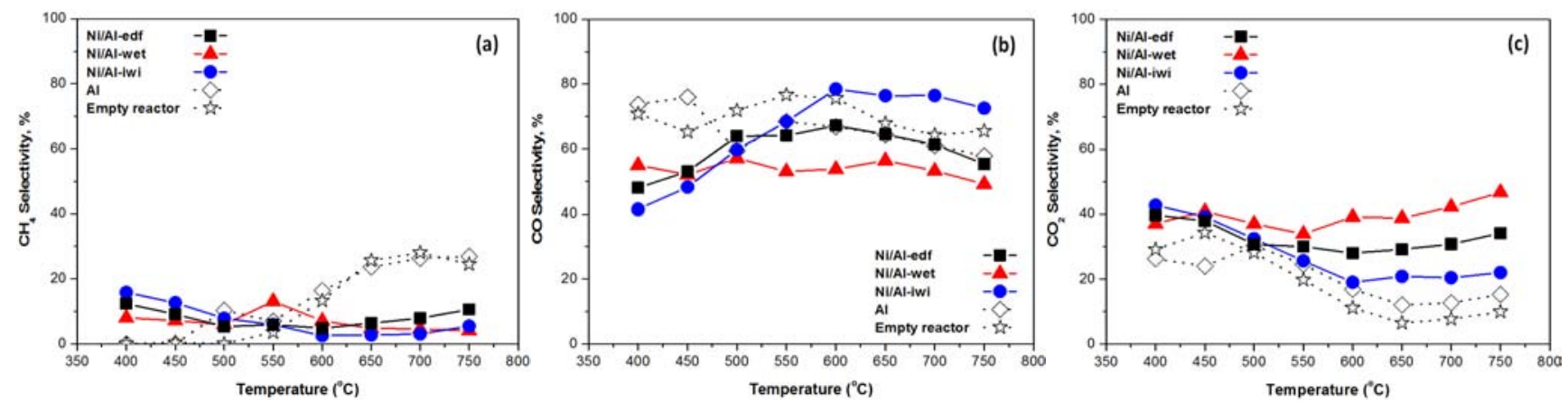

Fig. 8. Selectivities towards $\mathrm{CH}_{4}(\mathrm{a}), \mathrm{CO}(\mathrm{b})$ and $\mathrm{CO}_{2}$ (c). Reaction conditions: $\mathrm{C}_{3} \mathrm{H}_{8} \mathrm{O}_{3}\left(20\right.$ vol\%) $/ \mathrm{H}_{2} \mathrm{O}$ (total liquid flow rate $\left.=0.12 \mathrm{~mL} / \mathrm{min}\right) / \mathrm{He}(38$ $\mathrm{mL} / \mathrm{min}), w_{\text {catalyst }}=200 \mathrm{mg}, T=400-750^{\circ} \mathrm{C}$. 

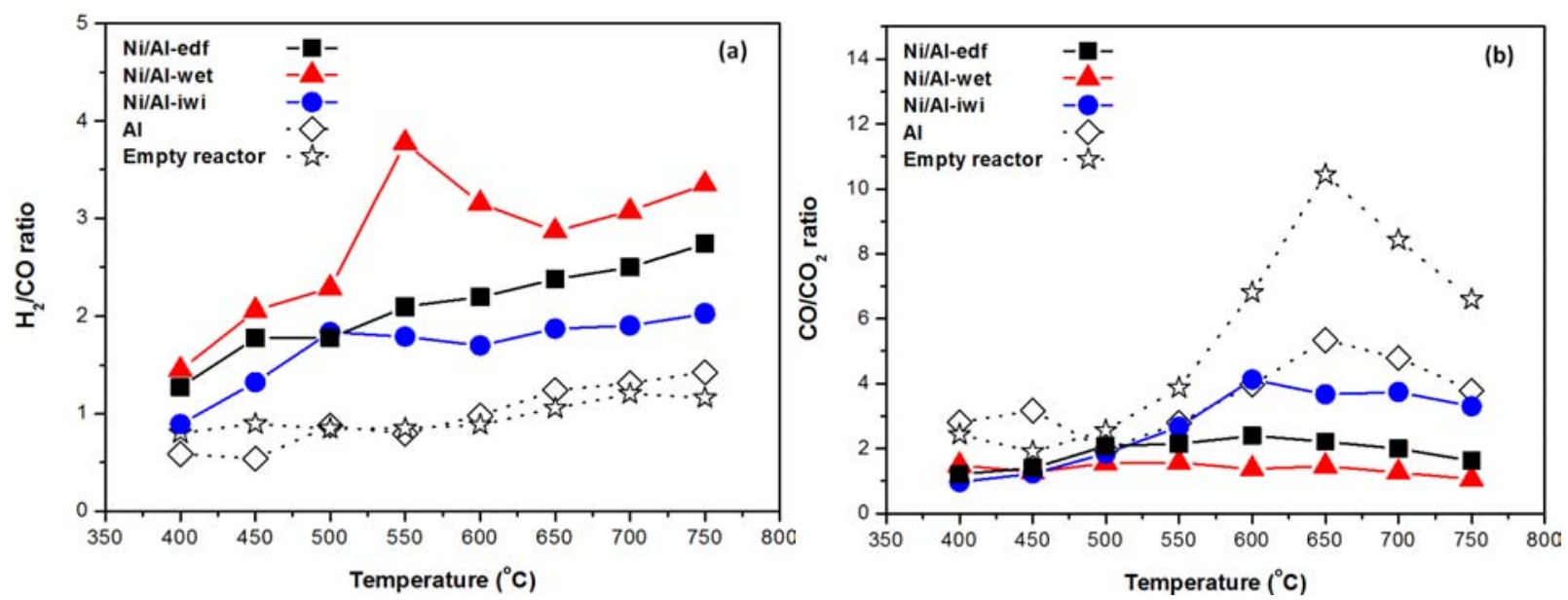

Fig. 9. $\mathrm{H}_{2} / \mathrm{CO}(\mathrm{a})$ and $\mathrm{CO} / \mathrm{CO}_{2}$ (b) ratios. Reaction conditions: $\mathrm{C}_{3} \mathrm{H}_{8} \mathrm{O}_{3}(20$ vol\% $) / \mathrm{H}_{2} \mathrm{O}$ (total liquid flow rate $\left.=0.12 \mathrm{~mL} / \mathrm{min}\right) / \mathrm{He}(38 \mathrm{~mL} / \mathrm{min}), w_{\text {catalyst }}=$ $200 \mathrm{mg}, \mathrm{T}=400-750^{\circ} \mathrm{C}$.

that the morphology of the solids is responsible for the different behavior of the catalyst during the reaction because the synthesis method is only difference between the three catalysts.

The methane concentration greatly decreased with increasing temperature for all the catalysts, meaning that methane SR has occurred to a major extent and most of the methane produced was converted into $\mathrm{H}_{2}$. The increasing $\mathrm{S}_{\mathrm{CO} 2}$ values and the rather constant $S_{\mathrm{CO}}$ above $550{ }^{\circ} \mathrm{C}$ indicate that both $\mathrm{Ni} / \mathrm{Al}$-wet and $\mathrm{Ni} / \mathrm{Al}$-edf catalysts successfully catalyze the WGS reaction. This can be also deduced from the trend observed in the $\mathrm{H}_{2} / \mathrm{CO}$ and $\mathrm{CO}_{2} / \mathrm{CO}$ molar ratios (Fig. 9). Catalyst active in the WGS (an overall exothermic system) normally exhibits characteristics that include available oxygen vacancies, activity in the dissociation of water, and low CO adsorption strength [42]. The intimated interaction between Ni particles and the alumina surface enhanced both glycerol reforming and WGS to improve $\mathrm{H}_{2}$ yield. The Ni particles activate chemisorbed glycer- ol and its derivatives while alumina assists water dissociation to form surface hydroxyl, which is key for the WGS reaction [43]. The WGS activity of the catalysts was dependent on their reduction degree, which can be ascribed to the different contribution of the nickel aluminate species ( $\beta$ - and $\gamma$-peaks) and also to the different contents of free $\mathrm{NiO}$ present on the catalysts [44].

\subsubsection{Liquid product selectivity}

The similarity in the product distribution for the noncatalytic (homogeneous) processes of the GSR with different steam-to-carbon molar ratios has been reported by Valliyappan et al. [45]. Glycerol was completely converted to gas and char during the steam gasification reaction at $700{ }^{\circ} \mathrm{C}$. Stein et al. [46] reported that the main liquid products detected for lower reaction temperatures and higher space velocities were acrolein and acetaldehyde for the noncatalytic GSR. Chiodo et al. [10] also reported that performing the homogenous GSR at $800{ }^{\circ} \mathrm{C}$

Table 2

Liquid products' distribution for all catalysts (Ni/Al-edf, Ni/Al-wet, Ni/Al-iwi), for calcined alumina (Al) and for the homogenous reaction at various reaction temperatures.

\begin{tabular}{|c|c|c|c|c|c|c|c|c|}
\hline \multirow{2}{*}{ Compound } & \multicolumn{8}{|c|}{ Liquid product distribution * } \\
\hline & $400^{\circ} \mathrm{C}$ & $450^{\circ} \mathrm{C}$ & $500^{\circ} \mathrm{C}$ & $550^{\circ} \mathrm{C}$ & $600^{\circ} \mathrm{C}$ & $650^{\circ} \mathrm{C}$ & $700^{\circ} \mathrm{C}$ & $750^{\circ} \mathrm{C}$ \\
\hline Acetaldehyde & $1,2,3,4,5$ & $1,2,3,4,5$ & $1,2,3,4,5$ & $1,2,3,4,5$ & $1,2,3,4,5$ & $1,2,3,4,5$ & 3,5 & 5 \\
\hline Acrolein & $1,2,3,4,5$ & $2,3,4,5$ & $3,4,5$ & - & - & - & - & - \\
\hline Acetone & $1,2,3,4,5$ & $1,2,3,4,5$ & $1,2,3,4,5$ & $1,2,3,4,5$ & $1,2,3,4,5$ & $1,2,3,4,5$ & $3,4,5$ & 4,5 \\
\hline Allyl alcohol & $1,2,3,4,5$ & $1,2,3,4,5$ & $1,2,3,4,5$ & $1,2,3,4,5$ & $1,2,3,5$ & $2,3,5$ & 5 & 5 \\
\hline Acetic acid & $1,2,3,4,5$ & $1,2,3,4,5$ & $1,2,3,4,5$ & $1,2,3,4,5$ & $1,2,3,4,5$ & $3,4,5$ & 4,5 & 4,5 \\
\hline Acetol & $1,2,3,4,5$ & $1,2,3,4,5$ & $1,2,3,4,5$ & $1,2,3,4,5$ & $1,2,3,4,5$ & $3,4,5$ & 4,5 & 4,5 \\
\hline 2-Cyclopenten-1-one & 2 & $1,2,4$ & $1,2,3,4$ & $1,2,3,4$ & 4 & - & - & - \\
\hline 2-Cyclopenten-1-one, 2-methyl & - & - & $2,3,4$ & $1,2,3,4$ & 4 & - & - & - \\
\hline Phenol & $1,2,3,4$ & $1,2,3,4$ & $1,2,3,4$ & $1,2,3,4$ & 3,4 & 4,5 & 4,5 & 4,5 \\
\hline Glycerol & $1,2,3,4,5$ & $1,2,3,4,5$ & $1,2,3,4,5$ & $1,2,3,4,5$ & $1,2,3,4,5$ & $1,2,3,4,5$ & $1,2,3,4,5$ & $1,2,3,4,5$ \\
\hline 2,3-Butanedione & 4,5 & $3,4,5$ & $2,3,4,5$ & $3,4,5$ & - & - & - & - \\
\hline Propylene glycol & $1,2,3,4,5$ & $2,3,4,5$ & 4,5 & 5 & 5 & - & - & - \\
\hline 1,2-Ethanediol & $3,4,5$ & $3,4,5$ & 4,5 & 5 & 5 & 5 & 5 & 5 \\
\hline Propanoic acid & - & 3 & 1,3 & 1 & 4 & - & - & - \\
\hline 2-Cyclohexen-1-one & - & - & 2 & - & - & - & - & - \\
\hline 1,3-Dioxan-5-ol & 4,5 & 4,5 & 4,5 & 4,5 & 4,5 & 4,5 & 4,5 & 4,5 \\
\hline Phenol, 2-methyl & 一 & 一 & 一 & - & 4 & - & - & 一 \\
\hline
\end{tabular}

$* 1=\mathrm{Ni} / \mathrm{Al}$-edf, $2=\mathrm{Ni} / \mathrm{Al}$-wet, $3=\mathrm{Ni} / \mathrm{Al}$-iwi, $4=\mathrm{Al}, 5=$ Empty reactor. 
decomposes glycerol to a mixture of gaseous $(65 \mathrm{~mol} \%$ conversion), and liquid products (30 mol\% conversion), resulting in a mixture of $\mathrm{CO}$ (50 mol\%), $\mathrm{CO}_{2}(1 \mathrm{~mol} \%)$, olefins (ethylene and propylene, $\sim 25 \mathrm{~mol} \%), \mathrm{CH}_{4}(\sim 13 \mathrm{~mol} \%)$, and $\mathrm{H}_{2}(\sim 10 \mathrm{~mol} \%)$.

The liquid product distributions for the GSR using all of our catalysts, calcined alumina and for the homogenous reaction in an empty reactor at various reaction temperatures are presented in Table 2. Acetaldehyde, acrolein, acetone, allyl alcohol, acetic acid, acetol and phenol were present for all experiments using reaction temperatures lower than $600{ }^{\circ} \mathrm{C}$ (except for acrolein that is only detected for $T<500{ }^{\circ} \mathrm{C}$ ). The aforementioned liquid products were detected at higher temperatures only for the Ni/Al-iwi, calcined alumina and homogeneous reaction experiments. Other substances were detected in trace amounts, such as 2-cyclopenten-1-one and 2-methyl-2-cyclopenten-1-one, were detected at $550-600{ }^{\circ} \mathrm{C}$, while 1,3-dioxan5 -ol was produced during the noncatalytic experiments for the whole temperature range. Substances such as 2,3-butanedione, propylene glycol and 1,2-ethanediol were identified as reaction products only at low temperatures $\left(T<550{ }^{\circ} \mathrm{C}\right)$ for the heterogeneous processes.

Table 3 presents the concentration values of the main liquid products at different reaction temperatures. These values are relatively low, never exceeding $10 \%$ for any particular substance, even at low temperatures. Acrolein was mainly produced at low reaction temperatures, namely lower than $500{ }^{\circ} \mathrm{C}$ for the blank reactor and with alumina or Ni/Al-iwi catalyst.
Acrolein was only detected for low temperature reactions for the Ni/Al-wet and Ni/Al-edf catalysts, up to 450 and $400{ }^{\circ} \mathrm{C}$, respectively, at quite low concentration ranging from 0.8 to 4.0 vol\%. Acetone was formed in much higher concentrations for all cases and for a broader reaction temperature range. Acetone was detected for temperatures as high as $750{ }^{\circ} \mathrm{C}$ for the blank reactor and alumina experiments, $700{ }^{\circ} \mathrm{C}$ for $\mathrm{Ni} / \mathrm{Al}$-iwi and 650 ${ }^{\circ} \mathrm{C}$ for $\mathrm{Ni} / \mathrm{Al}$-wet and $\mathrm{Ni} / \mathrm{Al}$-edf. Acetol, acetone, allyl alcohol and acetaldehyde appear at higher concentrations and more frequently for the catalytic samples compared with acetic acid and acrolein.

The influence of reaction temperature on the main liquid product selectivities, namely acetol ( $\left.S_{\text {acetol }}\right)$, acetone ( $\left.S_{\text {acetone }}\right)$, allyl alcohol ( $\left.S_{\text {allyl alcohol}}\right)$, acetaldehyde ( $\left.S_{\text {acetaldehyde }}\right)$, acetic acid ( $S_{\text {acetic acid }}$ ) and acrolein ( $S_{\text {acrolein }}$ is shown in Fig. 10. The main liquid products of the homogenous reaction were detected even at temperatures as high as $750{ }^{\circ} \mathrm{C}$ (Fig. 10(a)). A decrease in the $S_{\text {acetol, }} S_{\text {allyl alcohol }}$ and $S_{\text {acrolein }}$ values and an increase in the $S_{\text {acetone, }} S_{\text {acetaldehyde }}$ and $S_{\text {acetic acid }}$ were observed, with an almost equimolar liquid product mixture at $700{ }^{\circ} \mathrm{C}$ (acrolein was not detected for $T>550{ }^{\circ} \mathrm{C}$ ). A similar trend was seen for the calcined $\mathrm{Al}_{2} \mathrm{O}_{3}$ experiments (Fig. 10(b)), with the only difference being the disappearance of allyl alcohol and acetaldehyde at reaction temperatures higher than 600 and $700{ }^{\circ} \mathrm{C}$, respectively.

The main liquid products vary with reaction temperature for the Ni/Al catalysts (Fig. 10(c)-(e)). No liquid products were

Table 3

Concentrations of liquid products at various reaction temperatures.

\begin{tabular}{|c|c|c|c|c|c|c|c|c|c|}
\hline \multirow{2}{*}{ Catalyst } & \multirow{2}{*}{ Product } & \multicolumn{8}{|c|}{ Concentration (vol\%) } \\
\hline & & $400^{\circ} \mathrm{C}$ & $450^{\circ} \mathrm{C}$ & $500^{\circ} \mathrm{C}$ & $550^{\circ} \mathrm{C}$ & $600^{\circ} \mathrm{C}$ & $650^{\circ} \mathrm{C}$ & $700^{\circ} \mathrm{C}$ & $750^{\circ} \mathrm{C}$ \\
\hline \multirow[t]{6}{*}{ Blank experiment } & Acetol & 8.82 & 8.55 & 7.49 & 7.42 & 7.35 & 4.07 & 1.42 & 1.22 \\
\hline & Acetone & 3.54 & 3.07 & 2.74 & 2.56 & 2.53 & 2.52 & 2.48 & 2.20 \\
\hline & Allyl alcohol & 6.27 & 5.60 & 4.45 & 4.06 & 3.72 & 2.93 & 2.23 & 1.00 \\
\hline & Acetaldehyde & 5.85 & 4.77 & 4.59 & 4.47 & 4.23 & 3.84 & 2.71 & 2.16 \\
\hline & Acetic acid & 3.77 & 3.64 & 3.20 & 3.12 & 2.97 & 2.92 & 2.82 & 2.40 \\
\hline & Acrolein & 3.11 & 2.47 & 1.22 & 0.00 & 0.00 & 0.00 & 0.00 & 0.00 \\
\hline \multirow[t]{6}{*}{ Alumina } & Acetol & 8.09 & 7.95 & 7.15 & 5.39 & 1.43 & 1.38 & 1.35 & 1.31 \\
\hline & Acetone & 5.95 & 5.87 & 4.85 & 4.43 & 3.50 & 3.11 & 2.48 & 1.00 \\
\hline & Allyl alcohol & 4.11 & 3.72 & 3.63 & 2.80 & 0.00 & 0.00 & 0.00 & 0.00 \\
\hline & Acetaldehyde & 6.57 & 5.97 & 5.56 & 5.49 & 3.19 & 2.51 & 0.00 & 0.00 \\
\hline & Acetic acid & 3.28 & 3.28 & 3.04 & 2.80 & 2.79 & 2.55 & 2.37 & 2.21 \\
\hline & Acrolein & 4.38 & 3.96 & 2.63 & 0.00 & 0.00 & 0.00 & 0.00 & 0.00 \\
\hline \multirow[t]{6}{*}{ Ni/Al-edf } & Acetol & 6.55 & 6.06 & 5.57 & 4.03 & 0.26 & 0.00 & 0.00 & 0.00 \\
\hline & Acetone & 5.08 & 4.18 & 3.63 & 2.61 & 1.29 & 0.53 & 0.00 & 0.00 \\
\hline & Allyl alcohol & 3.16 & 2.90 & 2.07 & 1.33 & 1.26 & 0.00 & 0.00 & 0.00 \\
\hline & Acetaldehyde & 6.48 & 5.72 & 3.11 & 1.67 & 1.34 & 0.50 & 0.00 & 0.00 \\
\hline & Acetic acid & 2.18 & 1.99 & 1.47 & 1.31 & 1.11 & 0.00 & 0.00 & 0.00 \\
\hline & Acrolein & 1.72 & 0.00 & 0.00 & 0.00 & 0.00 & 0.00 & 0.00 & 0.00 \\
\hline \multirow[t]{6}{*}{ Ni/Al-wet } & Acetol & 6.46 & 6.39 & 5.75 & 4.06 & 0.11 & 0.00 & 0.00 & 0.00 \\
\hline & Acetone & 4.26 & 3.90 & 2.85 & 2.79 & 2.37 & 1.96 & 0.00 & 0.00 \\
\hline & Allyl alcohol & 2.70 & 2.20 & 1.58 & 1.46 & 1.21 & 0.28 & 0.00 & 0.00 \\
\hline & Acetaldehyde & 5.08 & 2.72 & 1.93 & 1.73 & 1.17 & 0.61 & 0.00 & 0.00 \\
\hline & Acetic acid & 2.34 & 1.69 & 1.55 & 1.36 & 0.94 & 0.00 & 0.00 & 0.00 \\
\hline & Acrolein & 2.07 & 1.03 & 0.00 & 0.00 & 0.00 & 0.00 & 0.00 & 0.00 \\
\hline \multirow[t]{6}{*}{$\mathrm{Ni} / \mathrm{Al}$-iwi } & Acetol & 6.29 & 5.83 & 5.75 & 4.40 & 4.09 & 0.33 & 0.00 & 0.00 \\
\hline & Acetone & 4.28 & 3.82 & 3.21 & 2.66 & 1.81 & 1.67 & 1.23 & 0.00 \\
\hline & Allyl alcohol & 3.74 & 3.50 & 3.49 & 3.14 & 2.05 & 1.45 & 0.00 & 0.00 \\
\hline & Acetaldehyde & 6.21 & 5.07 & 3.64 & 3.11 & 2.02 & 1.39 & 0.00 & 0.00 \\
\hline & Acetic acid & 2.09 & 1.75 & 1.71 & 1.50 & 1.37 & 1.22 & 0.56 & 0.00 \\
\hline & Acrolein & 1.85 & 1.11 & 0.86 & 0.00 & 0.00 & 0.00 & 0.00 & 0.00 \\
\hline
\end{tabular}




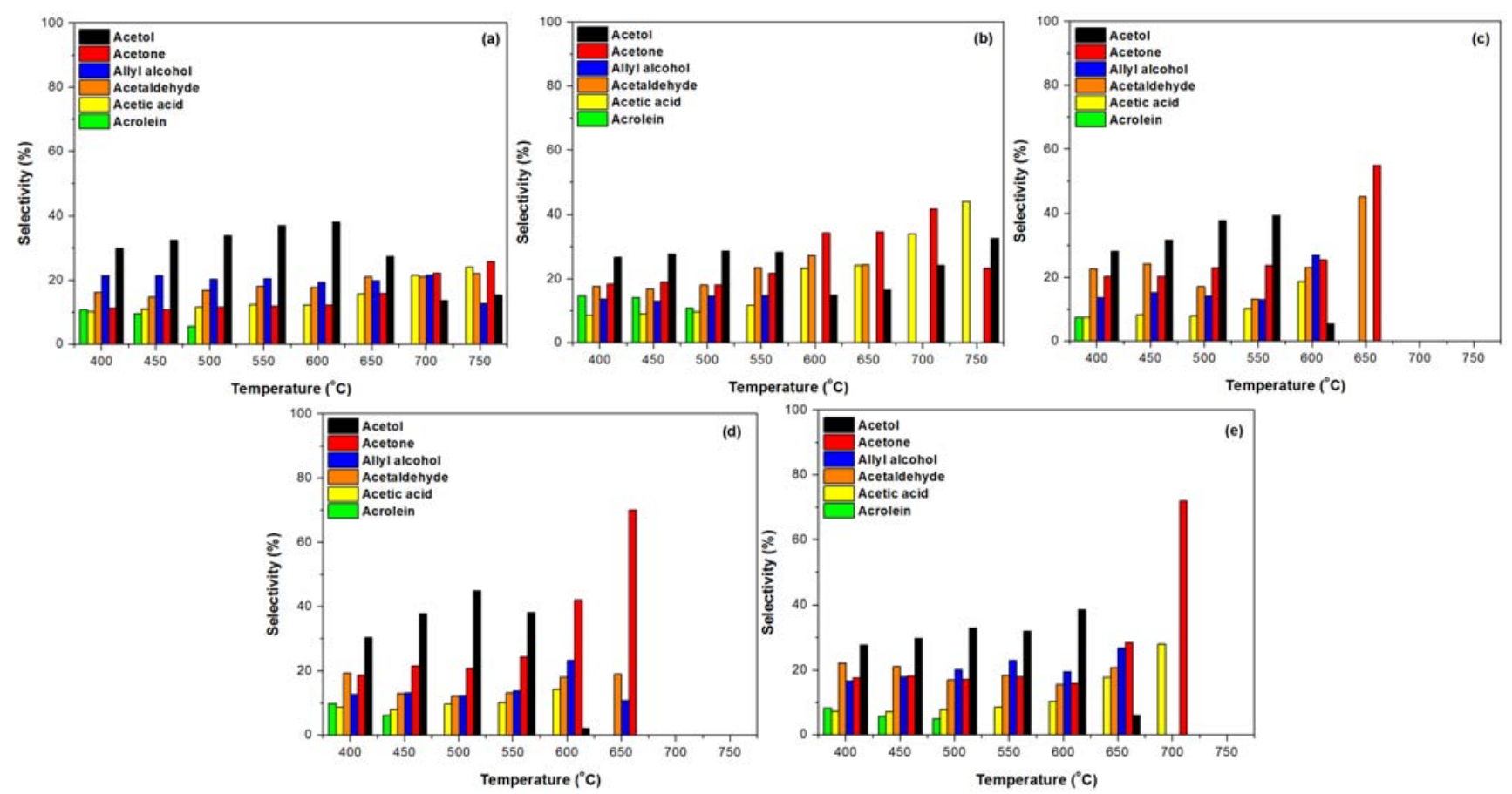

Fig. 10. Liquid product selectivity. (a) Blank reactor; (b) Alumina; (c) Ni/Al-edf; (d) Ni/Al-wet; (e) Ni/Al-iwi. Reaction conditions: $\mathrm{C}_{3} \mathrm{H}_{8} \mathrm{O}_{3}$ (20 vol\%) $/ \mathrm{H}_{2} \mathrm{O}$ (total liquid flow rate $\left.=0.12 \mathrm{~mL} / \mathrm{min}\right) / \mathrm{He}(38 \mathrm{~mL} / \mathrm{min}), w_{\text {catalyst }}=200 \mathrm{mg}, T=400-750{ }^{\circ} \mathrm{C}$.

detected for the $\mathrm{Ni} / \mathrm{Al}$-edf catalyst at temperatures higher than $650{ }^{\circ} \mathrm{C}$, suggesting that glycerol has been fully converted to gaseous products (Fig. 10(c)). The most interesting finding is that an almost equimolar mixture of acetone and acetaldehyde was produced at $650{ }^{\circ} \mathrm{C}$. The distribution of liquid products is quite different for the Ni/Al-wet catalyst at $T<650{ }^{\circ} \mathrm{C}$, and no liquid products were detected at higher reaction temperatures (Fig. 10(d)). The values of $S_{\text {acetone, }} S_{\text {acetaldehyde }}$ and $S_{\text {allyl alcohol }}$ at $650{ }^{\circ} \mathrm{C}$ were $70 \%, 19 \%$ and $11 \%$, respectively. It can be concluded that, as expected, the liquid product selectivities decrease with increasing temperature for all the catalysts. An equimolar amount of acetone and acetaldehyde was produced for the Ni/Al-edf catalyst at $650{ }^{\circ} \mathrm{C}$ (Fig. 10(c)), while the amounts of acetone, allyl alcohol and acetaldehyde were $70 \%$, $11 \%$ and $19 \%$, respectively for Ni/Al-wet (Fig. 10(d)). Acetol (6\%), acetone (28.5\%), allyl alcohol (26.5\%), acetaldehyde (21\%) and acetic acid (18\%) were detected for the Ni/Al-iwi catalyst at $650{ }^{\circ} \mathrm{C}$, with only acetone (72\%), acetic acid (28\%) at $700{ }^{\circ} \mathrm{C}$. Different liquid product distributions can be obtained by varying the synthesis method of the catalysts for the GSR.

The complexity of the reaction product mixture compositions (Table 2 and Fig. 10) and the dependence on glycerol's decomposition have been reported in the literature [47-51]. It has been confirmed that glycerol decomposes to $\mathrm{CO}, \mathrm{CO}_{2}$, olefins, water, hydrogen and oxygenates at high reaction temperatures in the gas phase. Therefore, the catalyst's ability to activate $\mathrm{C}-\mathrm{O}$ (typical of oxygenated compounds), $\mathrm{C}-\mathrm{C}$ and $\mathrm{C}=\mathrm{C}$ bonds should be taken into consideration. Olefins $\left(\mathrm{C}_{2} \mathrm{H}_{4}, \mathrm{C}_{3} \mathrm{H}_{6}\right)$ and $\mathrm{CO}$ are thought to be the main substances that reach the catalyst's surface; thus, it could be said that catalytic performance is dependent upon the tendency towards: (1) $C=C$ cleavage; and (2) coke formation inhibition by polymerization of $\mathrm{CH}_{x}$ species and/or $\mathrm{CO}$ dissociation (Boudouard reaction).

The liquid product distribution can be explained according to the reaction scheme proposed by Dumesic et al. [52], where the conversion of glycerol to hydrogen takes place through the formation of a variety of chemical intermediates, such as alcohols and ketones. A scheme of reactions involved in the GSR is presented in Scheme 1.

The dehydrogenation reactions of glycerol to acetol and glyceraldehyde, as well as its successive transformation to propanediol, are favored because of their small $\Delta G^{0}$ and $\Delta H^{0}$ values, resulting in the possible presence of these species during catalytic processes. Conversion to propanediol may take place first by dehydration of glycerol to 2-hydroxy-2-propenol and to acetol. In a following step, the $\mathrm{C}=\mathrm{C}$ or $\mathrm{C}=\mathrm{O}$ double bonds are hydrogenated to produce propanediol. This path can be performed over bi-functional catalysts, containing acid and base sites to achieve dehydration, as well as metal sites to facilitate hydrogenation reactions. The formation of synthesis gas (syngas) is highly endothermic and favorable at high temperatures. Syngas conversion is increased by decreasing in the number of Lewis acid sites on the catalyst, indicating that the basic sites favor the route to syngas conversion [53].

The Ni/Al-edf and Ni/Al-wet catalysts promote the formation of acetaldehyde and acetone, respectively (Table 3 and Fig. 10). The Ni/Al-iwi catalyst favors the production of allyl alcohol and acetic acid, as these can be detected even at high temperatures. Presumably these differences can be attributed to the varying abilities of the catalysts to promote the cleavage of $\mathrm{C}-\mathrm{C}, \mathrm{O}-\mathrm{H}$ and $\mathrm{C}-\mathrm{H}$ bonds in the oxygenated hydrocarbon reactant (leading to $\mathrm{H}_{2}$ and $\mathrm{CO}$ ) and facilitate the WGS reaction in order to remove adsorbed $\mathrm{CO}$ from the surface as $\mathrm{CO}_{2}$, as opposed to the cleavage of $\mathrm{C}-\mathrm{O}$ bonds that leads to alkanes. 


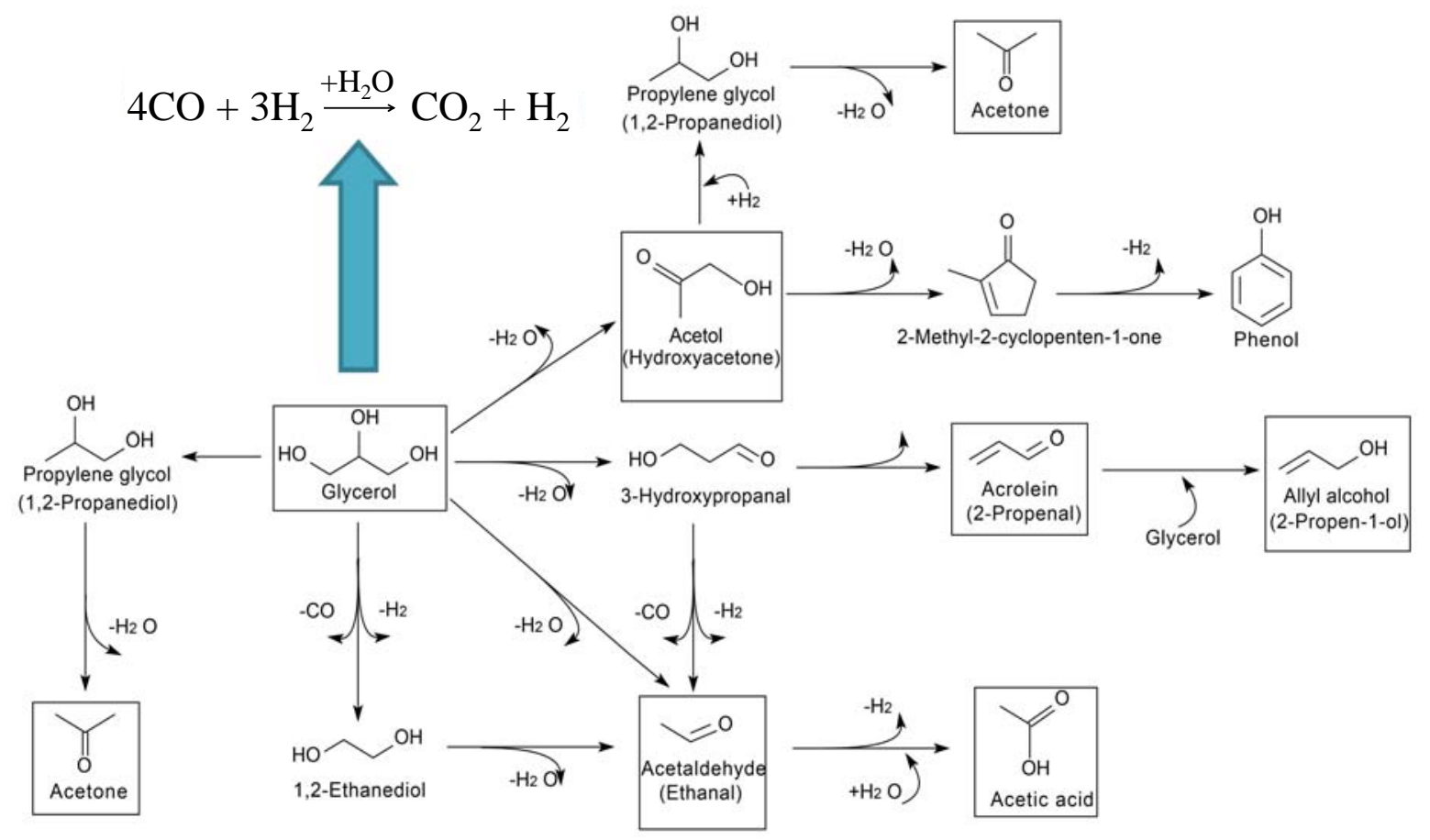

Scheme 1. Reaction pathway for the glycerol steam reforming reaction.

\subsubsection{Coke deposition}

The catalytic performances of the $\mathrm{Ni} / \mathrm{Al}$ catalysts described by the reaction metrics at $650{ }^{\circ} \mathrm{C}$, including the measured carbon deposition, are shown in Table 4 , as well as the results from experiments with calcined alumina and an empty reactor (homogenous reaction). The $\mathrm{Ni} / \mathrm{Al}$-edf catalyst gave the highest values of (1) glycerol to gaseous products conversion (88.74\%), (2) $\mathrm{H}_{2}$ yield (4.07 moles), (3) acetaldehyde selectivity $(45.11 \%)$, and lowest carbon deposition (12.3\%). The $\mathrm{Ni} / \mathrm{Al}$-wet has the highest values of (1) glycerol conversion (93.75\%), (2) $\mathrm{H}_{2}$ (69.33\%) and $\mathrm{CO}_{2}$ (38.31\%) selectivities, (3) acetone selectivity (70.16\%), (4) $\mathrm{H}_{2} / \mathrm{CO}$ molar ratio (2.87) and the lowest values of (1) glycerol conversion to gaseous products (79.56\%), (2) $\mathrm{CO}$ (56.43\%) selectivity, and $\mathrm{CO} / \mathrm{CO}_{2}$ molar ratio (1.45). The $\mathrm{Ni} / \mathrm{Al}$-iwi catalyst resulted in the highest values for (1) CO (76.39\%) and allyl alcohol (26.79\%), acetaldehyde $(20.72 \%)$, acetic acid (17.85\%) and acetol (6.06\%) selectivities, (2) $\mathrm{CO} / \mathrm{CO}_{2}$ molar ratio (3.67) and the lowest for (1) glycerol conversion (92.55\%), (2) $\mathrm{H}_{2}$ yield (3.72 moles) and selectivity (61.31\%), (3) $\mathrm{CO}_{2}$ selectivity (20.84\%), (4) acetone (28.58\%), selectivity, and $\mathrm{H}_{2} / \mathrm{CO}$ molar ratio (1.87).

The importance of studying carbon deposition during the (oxygenated) hydrocarbon reforming reaction is derived from the catalyst's deactivation, which is the main consequence of the undesirable carbon formation [54-56]. Previously reported experimental and theoretical studies have shown suppression of coke formation could be accomplished with high reaction temperatures and steam to carbon $(\mathrm{S} / \mathrm{C})$ molar ratios, and by adding oxygen in the feed $[3,57]$. The crucial role of the catalyst's specific characteristics on the reaction product distribution should be considered because the carbon gasification reac- tion may be rather kinetically slow. The pathways resulting in coke formation, such as thermolysis, oligomerization, and olefin formation via dehydration and decarbonylation should be carefully tailored. Dramatic $\mathrm{Ni} / \mathrm{Al}_{2} \mathrm{O}_{3}$ catalyst deactivation caused by carbonaceous deposits over the catalyst surface during reforming reactions has been previously verified $[16,58]$. It has been proposed that the coke deposition, associated with the dehydration, cracking and polymerization reactions, takes place on the alumina's surface acid sites [15]. Pant et al. [16] compared $\mathrm{Ni} / \mathrm{Al}_{2} \mathrm{O}_{3}$ with $\mathrm{Ni}$-ceria catalysts and reported sintering could be an alternative reason to carbon depo-

Table 4

Catalytic performance of the $\mathrm{Ni} / \mathrm{Al}$ catalysts at $650{ }^{\circ} \mathrm{C}$ and carbon measurements.

\begin{tabular}{|c|c|c|c|c|c|}
\hline Reaction metric & Ni/Al-edf & Ni/Al-wet & Ni/Al-iwi & $\gamma-\mathrm{Al}_{2} \mathrm{O}_{3}$ & $\begin{array}{l}\text { Empty } \\
\text { reactor }\end{array}$ \\
\hline$\overline{X_{\text {Сзн8оз }}(\%)}$ & 92.75 & 93.75 & 92.55 & 82.45 & 74.45 \\
\hline $\begin{array}{l}X_{\mathrm{C} 3 \mathrm{H} 803 \text { into gaseous }} \\
\text { products }(\%)\end{array}$ & 88.74 & 79.56 & 86.60 & 73.61 & 69.78 \\
\hline$Y_{\mathrm{H} 2}(\%)$ & 4.07 & 3.86 & 3.72 & 1.76 & 1.50 \\
\hline \multicolumn{6}{|l|}{ Selectivity (\%) } \\
\hline $\mathrm{H}_{2}$ & 65.57 & 69.33 & 61.31 & 34.21 & 30.74 \\
\hline $\mathrm{CO}_{2}$ & 29.11 & 38.81 & 20.84 & 12.05 & 6.50 \\
\hline $\mathrm{CO}$ & 64.50 & 56.43 & 76.39 & 64.34 & 67.88 \\
\hline $\mathrm{CH}_{4}$ & 6.39 & 4.76 & 2.77 & 23.61 & 25.62 \\
\hline Acetol & 0.00 & 0.00 & 6.06 & 16.52 & 27.47 \\
\hline Acetone & 54.89 & 70.16 & 28.58 & 34.72 & 15.86 \\
\hline Allyl alcohol & 0.00 & 10.82 & 26.79 & 0.00 & 19.91 \\
\hline Acetaldehyde & 45.11 & 19.02 & 20.72 & 24.41 & 21.05 \\
\hline Acetic acid & 0.00 & 0.00 & 17.85 & 24.34 & 15.71 \\
\hline Acrolein & 0.00 & 0.00 & 0.00 & 0.00 & 0.00 \\
\hline $\mathrm{H}_{2} / \mathrm{CO}$ ratio & 2.37 & 2.87 & 1.87 & 1.24 & 1.06 \\
\hline $\mathrm{CO} / \mathrm{CO}_{2}$ ratio & 2.22 & 1.45 & 3.67 & 5.34 & 10.43 \\
\hline Carbon (wt $\%)$ & 12.3 & 18.0 & 15.8 & $\mathrm{n} / \mathrm{a}$ & - \\
\hline
\end{tabular}

Note: $\mathrm{n} / \mathrm{a}=$ not available, $-=$ not applicable. 
sition for deactivation. The transition of alumina's crystalline phase during the reaction could be associated with sintering of the active Ni phase [17].

Studying the carbon deposition on the catalytic surface during the GSR is considered to be a major challenge [59,60]. The reactions that are responsible for coke accumulation are glycerol thermal decomposition [61] and the dehydration, dehydrogenation, and condensation of byproducts [62]. Coke formation has a strong dependence on glycerol concentration [59], and it is expected that sintering would accompany coke accumulation on a catalytic surface [63]. The phenomena of both sintering and coke formation during the GSR have also been reported in studies concerning the catalytic performance of supported Ru [10], Pt [64], and Ni [65] catalysts. Strategies to alleviate active phase sintering aim to strengthen the interactions between the catalytically active sites and the support's surface (strong metal-support interaction) by using other supporting materials, such as $\mathrm{CeO}_{2}$ [66], $\mathrm{TiO}_{2}$, or $\mathrm{ZrO}_{2}$ [13] or by incorporating promoters like alkaline ions (e.g., Kand Li) [67].

\subsection{Correlation of structure, dispersion and reducibility with catalytic performance}

The SSA for the reduced catalysts were approximately 177 , 159 and $156 \mathrm{~m}^{2} / \mathrm{g}$ for Ni/Al-edf, Ni/Al-wet and Ni/Al-iwi, respectively (Table 1). The adsorption $D_{\mathrm{a}}$ had values of $12.5,15.8$ and $17.0 \mathrm{~nm}$ for Ni/Al-edf, Ni/Al-wet and $\mathrm{Ni} / \mathrm{Al}$-iwi, respectively. The pore size distribution curves are single modal type in the mesopore range $(10-20 \mathrm{~nm})$ for all samples, being narrower and shifted to lower values for Ni/Al-edf (Fig. 2). The $\mathrm{Ni} / \mathrm{Al}$-edf catalyst, which had the highest values of glycerol to gaseous products conversion and $\mathrm{H}_{2}$ yield, as well as the lowest carbon deposition, also had the highest SSA and the lowest $D_{\text {a. }}$ This finding is quite reasonable as the Ni/Al-edf catalyst exhibited higher active phase dispersion and smaller $\mathrm{Ni}^{0}$ crystalline size compared with the other samples (as confirmed by TEM experimental results presented in [23]). The Ni/Al-iwi, having the lowest SSA and largest $\mathrm{Ni}^{0}$ crystalline size, had the highest $S$ co and the lowest glycerol conversion, $\mathrm{H}_{2}$ yield and selectivity, and $\mathrm{H}_{2} / \mathrm{CO}$ molar ratio.

According to Ewbank et al. [22] the nickel aluminate formation preparation method can affect the type of nickel species present on the alumina supported nickel catalyst. The formation of nickel aluminate is decreased by using mild conditions. This is the case for samples prepared by controlled adsorption, where the preparation method induces strong metalsupport interactions. The thermal energy of the system is great enough to overcome the 5-15 kJ/mol energy of metal-support bond once the reaction temperature exceeds $600{ }^{\circ} \mathrm{C}$, and the free $\mathrm{NiO}$ particles are found to be covered by nickel aluminate surface layers. Surface $\mathrm{NiAl}_{2} \mathrm{O}_{4}$ is the primary nickel species in the case of nickel samples prepared by dry impregnation. This has been confirmed by our TPR results (Fig. 4), which identified the different nickel species and showed their abundance depends on the preparation method.

The comparison between catalysts reveals that the catalyst synthesis method influenced their performance, mainly con- cerning gaseous and liquid product selectivities. The increases in $S_{\mathrm{CO} 2}$ and approximately constant $S_{\mathrm{CO}}$ for temperatures higher than $550{ }^{\circ} \mathrm{C}$ indicate that both the $\mathrm{Ni} / \mathrm{Al}$-wet and $\mathrm{Ni} / \mathrm{Al}$-edf successfully catalyze the WGS reaction. This can be also deduced from the observed trends in the $\mathrm{H}_{2} / \mathrm{CO}$ and $\mathrm{CO}_{2} / \mathrm{CO}$ molar ratios for both catalysts (Fig. 9).

As reported by Dou et al. [68], the reaction pathway for hydrogen production via the GSR may be considered to have three steps. During the first step, glycerol dehydrogenation results in CO species bonded onto the catalytic surface. At the second step, the CO species undergo desorption, and finally, WGS and methanation reactions occur in the third step. Adhikari et al. [3] evaluated an alumina-supported metal catalyst and found that at high reaction temperatures $\mathrm{H}_{2}$ production and selectivity values were enhanced up to $70 \%$. In a similar work by Czernik et al. [69], catalytic SR of biomass-derived liquids using a commercial nickel catalyst resulted in $\mathrm{H}_{2}$ yields approaching or exceeding $80 \%$ of those theoretically possible for stoichiometric conversion. A NiO/ $/ \mathrm{Al}_{2} \mathrm{O}_{3}$ catalyst that is typically used for steam methane reforming was tested for the GSR by Cheng et al. [5]; according to their results the steam-to-carbon molar ratios ranged from 1.1 to 4.0 for reaction temperatures between 450 and $550{ }^{\circ} \mathrm{C}$. These authors concluded that the main gaseous products were $\mathrm{H}_{2}, \mathrm{CO}_{2}$ and $\mathrm{CO}$, with a $\mathrm{H}_{2} / \mathrm{CO}_{2}$ ratio of approximately 2.15 , while the $\mathrm{H}_{2} / \mathrm{CO}$ ratio varied between 6.0 and 16.0 depending on the reactant feed composition. Other studies concerning the GSR with $\mathrm{Ni} / \mathrm{Al}_{2} \mathrm{O}_{3}$ catalysts have also shown, in accordance with our results, that higher $\mathrm{H}_{2}$ yield values could be attributed to the moderate reduction degree and higher dispersion of the active phase on the catalyst or, in other words, to the smaller particle size of nickel crystallites [70].

Chiodo et al. [10] reviewed the GSR using Ni and Rh catalyst and proposed, as main GSR reactions, glycerol decomposition, WGS and methane SR. Pompeo et al. [8] rationalized data of low temperature GSR experiments on Pt-based catalysts and concluded that apart from GSR, glycerol decomposition and WGS, the other major reaction to be considered is the methanation reaction and not methane SR. Dieuzeide et al. [51] performed a thermodynamic analysis of hydrogen production from the GSR using the stoichiometric method. Their main findings can be summarized as follows: glycerol conversion is complete in the equilibrium, product distribution is determined by WGS and methanation reactions, and at low temperature the methanation reaction is predominant over the WGS reaction, while at high temperatures the WGS predominates. The above reported mechanisms are in keeping with the increase of hydrogen yield and $\mathrm{S}_{\mathrm{CO} 2}$ with temperature, which are a result of the endothermic nature of the GSR. The $\mathrm{CO} / \mathrm{CO}_{2}$ ratio, which we found to be maximized at $600{ }^{\circ} \mathrm{C}$, could be related to a balance between the exothermic nature of glycerol hydrogenolysis and the endothermic nature of the GSR.

We found that the Ni/Al-edf and Ni/Al-wet catalysts promoted the formation of acetaldehyde and acetone, respectively. The Ni/Al-iwi catalyst seems to promote the production of allyl alcohol and acetic acid, as these products were detected even at high temperatures. The clarification of the GSR sequential reaction scheme, consisting of primary conversion into liquid 
products that are subsequently reformed to hydrogen and carbon oxides, could be modified by the glycerol's residence time. Liquid product can be categorized as follows (Fig. 10): (1) main liquid products that seem to be independent of the residence time, including dehydration products like hydroxyl-acetone $(\sim 40 \%)$ and dehydrogenation by-products like glyceraldehydes ( 20\%), which are both connected with the presence of catalyst's acid and basic sites; and (2) reaction sequence liquid products such as 1,2- and 1,3-propanediol, acrolein, acetone, propanal, methanol, ethanol, 2-propanol, formic, acetic and lactic acids, whose concentration depends on the residence time [53]. The aforementioned sequential reaction scheme for glycerol decomposition is in fair agreement with our experimental results and in accordance with the literature [70-72]. Coke can be produced from various sources, such as glycerol's oligomers, ethylene, acrolein or acetaldehyde [72-74].

\section{Conclusions}

In the present study, a series of $\mathrm{Al}_{2} \mathrm{O}_{3}$-supported $\mathrm{Ni}$ catalysts were synthesized, with nickel loading of $8 \mathrm{wt} \%$, using the incipient wetness, wet impregnation, and a modified EDF preparation methods. The formation of nickel aluminate phase for all catalysts was confirmed by the XRD and TPR results. The deconvolution of the reduction peaks revealed that the contribution of the $\beta$-peak in the $\mathrm{Ni} / \mathrm{Al}$-edf catalyst was higher than in the other two catalysts, indicating that these nickel aluminate species were more reducible.

The improved catalytic activity for gaseous products of $\mathrm{Ni} / \mathrm{Al}$-edf can be attributed to the surface nickel aluminate species that existing on the catalyst's surface under reaction conditions. The $\mathrm{H}_{2}$ yields of the catalysts were quite different at low temperatures (400-600 ${ }^{\circ} \mathrm{C}$ ), following the trend $\mathrm{Ni} / \mathrm{Al}$-wet > $\mathrm{Ni} / \mathrm{Al}$-edf $>\mathrm{Ni} / \mathrm{Al}$-iwi, while they are almost identical at high temperatures $\left(600-750{ }^{\circ} \mathrm{C}\right)$, reaching the value of 4 hydrogen moles. The catalysts' $S_{\mathrm{CO}}$ and $S_{\mathrm{CO} 2}$ can be explained by the varying degree of the reverse WGS reaction participation in the whole process reaction pathway, as the selectivities are quite different for reaction temperatures higher than $500{ }^{\circ} \mathrm{C}$. The $\mathrm{CO} / \mathrm{CO}_{2}$ molar ratio trend is quite different between the catalysts; it remains almost stable for the whole temperature range at 1.5 for $\mathrm{Ni} / \mathrm{Al}$-wet, and it reaches a peak at $650{ }^{\circ} \mathrm{C}$ for the $\mathrm{Ni} / \mathrm{Al}$-edf and $\mathrm{Ni} / \mathrm{Al}$-iwi catalysts with values of 2.3 and 4.2, respectively.

Acetaldehyde, acrolein, acetone, allyl alcohol, acetic acid, acetol and phenol were liquid products for all experiments at reaction temperatures lower than $650{ }^{\circ} \mathrm{C}$. The Ni/Al-edf catalyst had the highest values of (1) glycerol to gaseous products conversion (87.0\%), (2) $\mathrm{H}_{2}$ yield (4.4 moles), (3) allyl alcohol (27.0\%), acetaldehyde (23.1\%), and acetic acid (18.8\%) selectivities at a reaction temperature of $650{ }^{\circ} \mathrm{C}$ and with the lowest carbon deposition of all of the catalysts.

The Ni/Al-edf and Ni/Al-wet catalysts promote the formation of acetaldehyde and acetone, respectively. On the contrary, Ni/Al-iwi produces allyl alcohol and acetic acid. Presumably these differences can be attributed to the varying ability to promote cleavage of $\mathrm{C}-\mathrm{C}, \mathrm{O}-\mathrm{H}$ and $\mathrm{C}-\mathrm{H}$ bonds in the oxygenat- ed hydrocarbon reactant (leading to $\mathrm{H}_{2}$ and $\mathrm{CO}$ ) and to facilitate the WGS in order to remove adsorbed CO from the surface as $\mathrm{CO}_{2}$, as opposed to the cleavage of $\mathrm{C}-\mathrm{O}$ bonds (leading to alkanes).

The preparation method influenced the physicochemical properties of the $\mathrm{Ni} / \mathrm{Al}_{2} \mathrm{O}_{3}$ catalysts and thus the selectivity to gaseous and liquid products, as well as their resistance to carbon deposition.

\section{Acknowledgments}

Financial support by the program THALIS implemented within the framework of Education and Lifelong Learning Operational Programme, co-financed by the Hellenic Ministry of Education, Lifelong Learning and Religious Affairs and the European Social Fund, for the project 'Production of Energy Carriers from Biomass by Products. Glycerol Reforming for the Production of Hydrogen, Hydrocarbons and Superior Alcohols' is gratefully acknowledged. Moreover, the authors also wish to acknowledge financial support provided by the Committee of the Special Account for Research Funds of the Technological Educational Institute of Western Macedonia (ELKE, TEIWM).

\section{References}

[1] X. D. Wang, S. R. Li, H. Wang, B. Liu, X. B. Ma, Energy Fuels, 2008, $22,4285-4291$.

[2] J. M. Silva, M. A. Soria, L. M. Madeira, Renew. Sustain. Energy Rev., 2015, 42, 1187-1213.

[3] S. Adhikari, S. Fernando, A. Haryanto, Catal. Today, 2007, 129, 355-364.

[4] I. N. Buffoni, F. Pompeo, G. F. Santori, N. N. Nichio, Catal. Commun., 2009, 10, 1656-1660.

[5] C. K. Cheng, S. Y. Foo, A. A. Adesina, Catal. Today, 2011, 178, 25-33.

[6] C. A. Franchini, W. Aranzaez, A. M. D. de Farias, G. Pecchi, M. A. Fraga, Appl. Catal. B, 2014, 147, 193-202.

[7] A. C. D. Freitas, R. Guirardello, Int. J. Hydrogen Energy, 2014, 39, 17969-17984.

[8] F. Pompeo, G. F. Santori, N. N. Nichio, Catal. Today, 2011, 172, 183-188.

[9] R. R. Soares, D. A. Simonetti, J. A. Dumesic, Angew. Chem. Int. Ed., 2006, 45, 3982-3985.

[10] V. Chiodo, S. Freni, A. Galvagno, N. Mondello, F. Frusteri, Appl. Catal. A, 2010, 381, 1-7.

[11] T. Hirai, N. O. Ikenaga, T. Miyake, T. Suzuki, Energy Fuels, 2005, 19, 1761-1762.

[12] S. Adhikari, S. D. Fernando, A. Haryanto, Renew Energy, 2008, 33, 1097-1100.

[13] V. Nichele, M. Signoretto, F. Menegazzo, A. Gallo, V. D. Santo, G. Cruciani, G. Cerrato, Appl. Catal. B, 2012, 111, 225-232.

[14] B. L. Dou, C. Wang, Y. C. Song, H. S. Chen, Y. J. Xu, Energy Convers. Manage, 2014, 78, 253-259.

[15] M. Ni, D. Y. C. Leung, M. K. H. Leung, Int. J. Hydrogen Energy, 2007, 32, 3238-3247.

[16] K. K. Pant, R. Jain, S Jain, Korean J. Chem. Eng., 2011, 28, 1859-1866.

[17] J. G. Seo, M. H. Youn, S. Park, J. S. Chung, I. K. Song, Int. J. Hydrogen Energy, 2009, 34, 3755-3763.

[18] C. Jiménez-González, Z. Boukha, B. de Rivas, J. J. Delgado, M. A. 
Cauqui, J. R. González-Velasco, J. I. Gutiérrez-Ortiz, R. López-Fonseca, Appl. Catal. A, 2013, 466, 9-20.

[19] N. Salhi, A. Boulahouache, C. Petit, A. Kiennemann, C. Rabia, Int. J. Hydrogen Energy, 2011, 36, 11433-11439.

[20] Z. Boukha, C. Jiménez-González, B. de Rivas, J. R. González-Velasco, J. I. Gutiérrez-Ortiz, R. López-Fonseca, Appl. Catal. B, 2014, 158-159, 190-201.

[21] I. E. Achouri, N. Abatzoglou, C. Fauteux-Lefebvre, N. Braidy, Catal. Today, 2013, 207, 13-20.

[22] J. L. Ewbank, L. Kovarik, F. Z. Diallo, C. Sievers, Appl. Catal. A, 2015, 494, 57-67.

[23] M. A. Goula, N. D. Charisiou, K. N. Papageridis, A. Delimitis, E. Pachatouridou, E. F. Iliopoulou, Int. J. Hydrogen Energy, 2015, 40, 9183-9200.

[24] C. Papadopoulou, J. Vakros, H. K. Matralis, C. Kordulis, A. Lycourghiotis, J. Colloid Interf. Sci., 2003, 261, 146-153.

[25] O. A. Bereketidou, M. A. Goula, Catal. Today, 2012, 195, 93-100.

[26] M. Thommes, K. Kaneko, A. V. Neimark, J. P. Olivier, R. F. Rodriguez, J. Rouquerol, K. S. W. Sing, Pure Appl. Chem., 2015, 87, 1051-1069.

[27] A. Bazyari, Y. Mortazavi, A. A. Khodadadi, L. T. Thompson, R. Tafreshia, A. Zaker, O. T. Ajenifujah, Appl. Catal. B, 2016, 180, 312-323.

[28] G. Garbarino, S. Chitsazan, T. K. Phung, P. Riani, G. Busca, Appl. Catal. A, 2015, 505, 86-97.

[29] G. H. Li, L. J. Hu, J. M. Hill, Appl. Catal. A, 2006, 301, 16-24.

[30] H. S. Roh, K. W. Jun, S. E. Park, Appl. Catal. A, 2003, 251, 275-283.

[31] P. Kim, Y. Kim, H. Kim, I. K. Song, K. Yi, Appl. Catal. A, 2004, 272, $157-166$

[32] Y. Choi, N. D. Kim, J. Back, W. Kim, H. J. Lee, J. Yi, Int. J. Hydrogen
Energy, 2011, 36, 3844-3852.

[33] R. C. Yang, X. G. Li, J. S. Wu, X. Zhang, Z. H. Zhang, Y. F. Cheng, J. T. Guo, Appl. Catal. A, 2009, 368, 105-112.

[34] P. H. Bolt, F. H. P. M. Habraken, J. W. Geus, J. Catal., 1995, 151, 300-306.

[35] A. Al-Ubaid, E. E. Wolf, Appl. Catal., 1998, 40, 73-85.

[36] J. R. H. Ross, M. C. F. Steel, A. Zeini-Isfahani, J. Catal., 1978, 52, 280-290.

[37] X. D. Wang, M. S. Li, S. R. Li, H Wang, S. P. Wang, X. B. Ma, Fuel Process Technol., 2010, 91, 1812-1818.

[38] S. Authayanun, A. Arpornwichanop, W. Paengjuntuek, S. Assabumrungrat, Int. J. Hydrogen Energy, 2010, 35, 6617-6623.

[39] Y. S. Seo, A. Shirley, S. T. Kolaczkowski, J. Power Sources, 2002, $108,213-225$.

[40] M. Ashrafi, T. Proll, C. Pfeifer, H. Hofbauer, Energy Fuels, 2008, 22, 4182-4189.

[41] S. Adhikari, S. Fernando, S. R. Gwaltney, S. D. Filipito, R. Mark Bricka, P. H. Steele, A. Haryanto, Int. J. Hydrogen Energy, 2007, 32, 2875-2880.

[42] T. L. Le Valley, A. R. Richard, M. Fan, Int. J. Hydrogen Energy, 2014, 39, 16983-17000.

[43] B. C. Zhang, X. L. Tang, Y. Li, Y. D. Xu, W. J. Shen, Int. J. Hydrogen Energy, 2007, 32, 2367-2373.

[44] M. C. Tang, L. Xu, M. H. Fan, Appl. Energy, 2015, 151, 143-156.

[45] T. Valliyappan, D. Ferdous, N. N. Bakhshi, A. K. Dalai, Top. Catal., 2008, 49, 59-67.

[46] Y. S. Stein, M. J. Antal Jr, M. A. Jones Jr, J. Anal. Appl. Pyrolysis, 1983, 4, 283-296.

[47] S. Adhikari, S. D. Fernando, A. Haryanto, Energy Convers. Manage., 2009, 50, 2600-2604.

\section{Graphical Abstract}

Chin. J. Catal., 2016, 37: 1949-1965 doi: 10.1016/S1872-2067(16)62518-4

Influence of the synthesis method parameters used to prepare nickel-based catalysts on the catalytic performance for the glycerol steam reforming reaction

M. A. Goula*, N. D. Charisiou, K. N. Papageridis, G. Siakavelas

Technological Education Institution of Western Macedonia, Greece

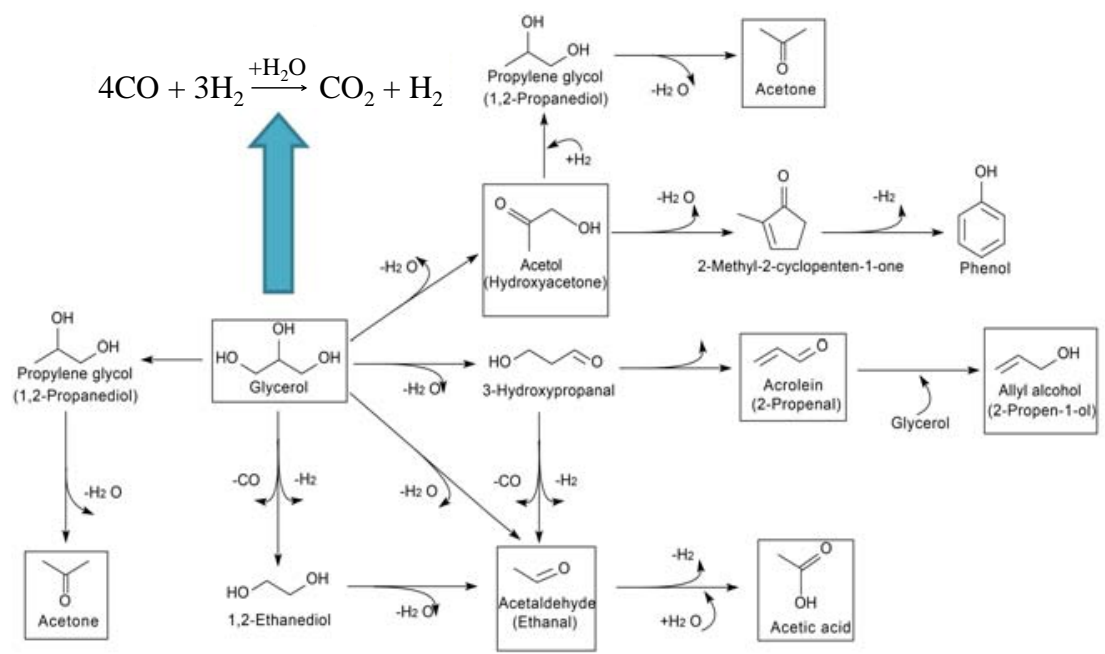

This article focused on the investigation of the role of the synthesis method for nickel-based catalysts on the catalytic performance for the glycerol steam reforming reaction. 
[48] H. Atia, U. Armbruster, A. Martin, J. Catal., 2008, 258, 71-82.

[49] W. Suprun, M. Lutecki, T. Haber, H. Papp, J. Mol. Catal. A, 2009, 309, 71-78.

[50] Y. Li, X. X. Wang, C. Xie, C. S. Song, Appl. Catal. A, 2009, 357, 213-222.

[51] M. L. Dieuzeide, N. Amadeo, Chem. Eng. Technol., 2010, 33, 89-96.

[52] D. A. Simonetti, J. A. Dumesic, Catal. Rev. Sci. Eng., 2009, 51, 441-484.

[53] L. F. Bobadilla, A. Penkova, F. Romero-Sarria, M. A. Centeno, J. A. Odriozola, Int. J. Hydrogen Energy, 2014, 39, 5704-5712.

[54] A. M. D. Douette, S. Q. Turn, W. Wang, V. I. Keffer, Energy Fuels, 2007, 21, 3499-3504.

[55] M. Slinn, K. Kendall, C. Mallon, J. Andrews, Bioresour. Technol., 2008, 99, 5851-5858.

[56] M. A. Goula, A. A. Lemonidou, A. M. Efstathiou, J. Catal., 1996, 161, 626-640.

[57] W. J. Cai, F. G. Wang, E. S. Zhan, A. C. Van Veen, C. Mirodatos, W. J. Shen, J. Catal., 2008, 257, 96-107.

[58] G. D. Wen, Y. P. Xu, H. J. Ma, Z. S. Xu, Z. J. Tian, Int. J. Hydrogen Ener$g y, \mathbf{2 0 0 8}, 33,6657-6666$.

[59] C. K. Cheng, S. Y. Foo, A. A. Adesina, Ind. Eng. Chem. Res., 2010, 49, 10804-10817.

[60] S. Adhikari, S. D. Fernando, S. D. F. To, R. M. Bricka, P. H. Steele, A. Haryanto, Energy Fuels, 2008, 22, 1220-1226.

[61] B. Dou, V. Dupont, P. T. Williams, H. Chen, Y. Ding, Bioresour. Technol., 2009, 100, 2613-2620.

[62] A. N. Fatsikostas, D. I. Kondarides, X. E. Verykios, Catal. Today,
2002, 75, 145-155.

[63] Y. C. Lin, Int. J. Hydrogen Energy, 2013, 38, 2678-2700.

[64] T. Montini, R. Singh, P. Das, B. Lorenzut, N. Bertero, P. Riello, A. Benedetti, G. Giambastiani, C. Bianchini, S. Zinoview, S. Miertus, P. Fornasiero, ChemSusChem, 2010, 3, 619-628.

[65] A. Iriondo, V. L. Barrio, J. F. Cambra, P. L. Arias, M. B. Guemez, M. C. Sanchez-Sanchez, R. M. Navarro, J. L. G. Fierro, Int. J. Hydrogen Energy, 2010, 35, 11622-11633.

[66] M. Araque, L. M. T. Martínez, J. C. Vargas, A. C. Roger, Catal. Today, 2011, 176, 352-356.

[67] F. Frusteri, S. Freni, V. Chiodo, L. Spadaro, O. di Blasi, G. Bonura, S. Cavallaro, Appl. Catal. A, 2004, 270, 1-7.

[68] B. L. Dou, Y. C. Song, C. Wang, H. S. Chen, Y. J. Xu, Renew. Sustain. Energy Rev., 2014, 30, 950-960.

[69] S. Czernik, R. French, C. Feik, E. Chornet, Ind. Eng. Chem. Res., 2002, 41, 4209-4215.

[70] G. W. Wu, C. X. Zhang, S. R. Li, Z. P. Han, T. Wang, X. B. Ma, J. L. Gong, ACS Sustain. Chem. Eng., 2013, 1, 1052-1062.

[71] A. Corma, G. W. Huber, L. Sauvanaud, P. O'Connor, J. Catal., 2008, 257, 163-171.

[72] K. N. Papageridis, G. Siakavelas, N. D. Charisiou, D. G. Avraam, L. Tzounis, K. Kousi, M. A. Goula, Fuel Process. Technol., 2016, 152, 156-175.

[73] J. Barrault, J. M. Clacens, Y. Pouilloux, Top. Catal., 2004, 27, 137-142.

[74] A. G. Gayubo, A. T. Aguayo, A. Atutxa, R. Aguado, J. Bilbao, Ind. Eng. Chem. Res., 2004, 43, 2610-2618.

\title{
制备条件对用于甘油蒸汽重整反应Ni基催化剂性能的影响
}

\author{
M. A. Goula*, N. D. Charisiou, K. N. Papageridis, G. Siakavelas \\ 西马其顿技术教育学院技术应用学院环境与污染控制工程系替代燃料与环境催化实验室, 科扎尼, 希腊
}

摘要: 研究了制备参数对用于甘油蒸汽重整反应的 $\mathrm{Ni}$ 基催化剂性能的影响. 采用过量浸渍法、等体积浸渍法和改进的平衡 沉积过滤 $(\mathrm{EDF})$ 法制备了一系列 $\mathrm{Al}_{2} \mathrm{O}_{3}$ 负载的 $8 \mathrm{wt} \% \mathrm{Ni}$ 催化剂, 运用 $\mathrm{X}$ 射线衍射 $\mathrm{XRD}$ )、电感耦合等离子体光谱仪、 $\mathrm{N}_{2}$ 吸附脱附、扫描电镜(SEM)、透射电镜和 $\mathrm{H}_{2}$ 程序升温还原(TPR)表征了催化剂的表面和体相性质; 采用CHN分析仪和SEM表征 了使用后催化剂以测定其表面沉积的碳及其形貌. 结果表明, 制备方法对所制催化剂的织构、结构和表面性质影响很大, 导致氧化铝表面 $\mathrm{Ni}$ 物种的分散和种类的不同. 即使XRD和TPR结果证实形成了铝酸镍晶相, 但 Ni/Al-edf催化剂中 $\beta$ 峰的贡 献大于其它两个催化剂的, 表明在这种情况下铝酸镍更容易还原. 在 $550{ }^{\circ} \mathrm{C}$ 以上 $\mathrm{CO}_{2}$ 选择性增加和 $\mathrm{CO}$ 选择性不变, 表明 $\mathrm{Ni} / \mathrm{Al}$-wet和 Ni/Al-edf催化剂可成功催化水汽变换反应. 另外, $650{ }^{\circ} \mathrm{C}$ 时 Ni/Al-edf催化剂上甘油生成气相产物的转化率、氢 气产率以及烯丙醇、乙醄和乙酸选择性最高, 且它在所有催化剂中的积炭量也最低. 将催化剂结构性质、分散度和还原性 与其催化性能相关联, 发现EDF法制得的催化剂比表面积和活性相分散度更高, 更易被还原, 因而其活性和生成 $\mathrm{H}_{2}$ 的选择 性更高, 也更抗积碳.

关键词: 甘油; 氢气; 蒸汽重整; 负载型镍催化剂; 催化剂制备

收稿日期: 2016-05-31. 接受日期: 2016-07-24. 出版日期: 2016-11-05.

*通讯联系人. 电话: +30-2461068296; 传真: +30-2461039682; 电子信箱: mgoula@teiwm.gr

本文的英文电子版由Elsevier出版社在ScienceDirect上出版(http://www.sciencedirect.com/science/journal/18722067). 